\title{
Testicular histology of Anurans that deposit eggs out of the water
}

\author{
Histología testicular de Anuros que depositan huevos \\ fuera del agua
}

\begin{abstract}
Ana Pucci Alcaide ${ }^{*}$, Franco Pucci Alcaide², Adriana Azucena Michel2, María Laura Ponssa ${ }^{3}$

1* Cátedra de Histología, Facultad de Ciencias Naturales e Inst. Miguel Lillo, Universidad Nacional de Tucumán. Miguel Lillo 205, (4000) S. M. de Tucumán, Argentina. anapucci76@gmail.com

2 Instituto de Morfología Animal, Dirección Zoología, Fundación Miguel Lillo. Miguel Lillo 251, (4000) S. M. de Tucumán, Argentina.

3 Unidad Ejecutora Lillo (U.E.L.), CONICET - Fundación Miguel Lillo. Miguel Lillo 251, (4000) S. M. de Tucumán, Argentina.
\end{abstract}

\begin{abstract}
Anuran amphibians show the largest diversity of amphibian reproductive modes, many of which imply egg deposition out of the water. This kind of egg deposition requires specialisations to avoid egg desiccation. Physiological, anatomical and ethological traits integrate to define these modes. In particular, morphological features of the urogenital system correlate with these reproductive modes and the environmental conditions where egg-laying occurs. In this study $y_{2}$ we describe the testicular histology and spermatogenesis of the nest-building frog Leptodactylus latinasus, and we compare it with other species that breed out of water. We found variations in testis size, the thickness of interstitial tissue, tunica albuginea, and peritubular tunics, flagellum length, and in the shape and size of the spermatozoal nucleus. Certain specifics' characters differed at the species level, but not between families. Such variation could be an indicator of spermatozoal performance and environmental constraints under which fertilisation takes place.
\end{abstract}

Keywords - Anurans, terrestrial reproduction, testicle, histology.

Ref. bibliográfica: Pucci Alcaide, A.; Pucci Alcaide, F.; Michel, A. A.; Ponssa, M. L. 2020. Testicular histology of Anurans that deposit eggs out of the water. Acta zoológica lilloana 64 (2): 84-115. Fundación Miguel Lillo, Tucumán, Argentina. D.O.I.: https://doi.org/10.30550/j.azl/2020.64.2/2

> Recibido: 6 de abril 2020 - Aceptado: 7 de agosto 2020 .

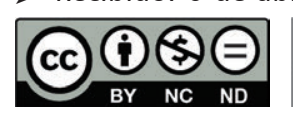




\section{RESUMEN}

Los anfibios anuros muestran la mayor diversidad de modos reproductivos, muchos de los cuales implican la deposición de huevos fuera del agua. Este tipo de puesta requiere de especializaciones para evitar la desecación de la puesta. Los rasgos fisiológicos, anatómicos y etológicos se han integrado para definir estos modos. En particular, las características morfológicas del sistema urogenital se correlacionan con estos modos reproductivos y las condiciones ambientales donde tiene lugar la puesta. En este estudio describimos la histología de los testículos y la espermatogénesis de la rana excavadora Leptodactylus latinasus y se las compara con otras especies que se reproducen fuera del agua. Encontramos variaciones en el tamaño de los testículos, el grosor del tejido intersticial, la túnica albugínea y peritubular, la longitud del flagelo, forma y tamaño del núcleo del espermatozoide. Ciertos caracteres específicos difieren a nivel de especie y no entre familias. Tal variación podría ser un indicador del desempeño de los espermatozoides y de las limitaciones ambientales bajo las cuales tiene lugar la fertilización.

Palabras clave - Anuros, reproducción terrestre, testículo, histología.

\section{INTRODUCTION}

Among vertebrates, anuran amphibians have the highest diversity of reproductive modes (Salthe and Duellman, 1973; Taylor and Gutman, 1977; Duellman and Trueb, 1986; Haddad and Prado, 2005). These modes have been characterised based on features describing the different stages of the reproductive function, such as amplexus type, number and size of eggs, oviposition frequency, deposition place, breeding sites, parental care. (Duellman, 1985; Lavilla and Rougés, 1992; Lavilla, 2004; Haddad and Prado, 2005). Physiological, anatomical, and ethological traits have been integrated to define these modes. In particular, morphological features of the urogenital system are correlated with these reproductive modes (Oliveira, Zanettoni and Zieri, 2002; Alcaide, Lavilla, and Pucci Alcaide, 2009; Leite, Franco-Belluci, Provete and Oliveira, 2015).

In anurans, the most generalised and phylogenetically prevalent oviposition site is water (Duellman and Trueb, 1986); nevertheless, among the reproductive modes described by Duellman and Trueb (1986), 18 of 29 categories exhibit terrestrial or arboreal egg depositions. Such deposition out of the water has been proposed as an adaptation against aquatic predators (Magnusson and Hero, 1991; Martins, 1993). This behaviour would imply an extra cost since the eggs and hatchlings would be under the pressure of terrestrial predators (Downie, Disney, Collins, and Hancok, 1995; Prado, Toledo, Zina, and Haddad, 2005; Lingnau and Di-Bernardo, 2006; Ponssa and Barrionuevo, 2008).

When eggs are laid outside of water (e.g. in mosses, wet ground land, moist soil, holes, leaves hanging from trees, mud chambers, natural burrows, or trees), larval development continues with a passive fall or active displacement to water, 
where free-living larval development is completed (Noble, 1927; Salthe and Mecham, 1974; Duellman and Trueb, 1986; Wells, 2007). This type of egg deposition requires specialisations to avoid egg desiccation. For example, the vesicles found in nests of Phyllomedusa sauvagii frogs are filled with metabolic water, which plays a key role in maintaining an appropriate humid environment for eggs and their embryonic development (Pyburn, 1980; Pucci Alcaide, Alcaide, Pucci Alcaide, and Lavilla, 2011). These vesicles originate from glycoconjugates, proteins, and lipids secreted in the preconvolute and convolute parts, and organise in the oviductal lumen; at least four types can be recognised according to their content (Pucci Alcaide et al., 2011). Another example is the foam generated by tadpoles of certain Leptodactylus species, which prevents from desiccation when the dry season lasts longer (Downie, 1984; Caldwell and Lopez, 1989; Downie, 1990; Downie and Smith, 2003; Ponssa and Barrionuevo, 2008).

In regard to the male reproductive system, testes have been studied in certain anuran species (Oliveira et al., 2002; Oliveira, Sant'Anna, Munhoz de Omena, Souza Santos, Zieri, 2003; Oliveira and Zieri, 2005; Asenjo, Siu Ting, and Pino, 2011; Leite et al., 2015; among many other). Particularly, sperm morphology and ultrastructure have been used to infer taxonomic and phylogenetic relationships in Ascaphus (Jamieson, Lee, and Long, 1993), Colostethus (Veiga-Menoncello, Lima, and Recco-Pimentel, 2006), certain Hylidae species, (Lee and Jamieson, 1993), Leiopelma (Scheltinga, Jamieson, Eggers, and Green, 2001), Leptodactylinae (Salles, Zara, and Prado, 2017), Myobatrachids (Lee and Jamieson, 1993), Pleurodema (Cruz, Ferraro, Farías, Santos, Recco-Pimentel, Faivovich, and Hermida, 2016); Pseudopaludicola (dos Santos, Orlandi Introíni, Prado Veiga-Menoncello, and Recco-Pimentel, 2015), and Pseudinae (Garda, Costa, Colli, and Báo, 2004). Spermiogenesis has also been studied in association with different types of fertilisation since spermatozoon morphology is thought to be the result of evolutionary pressure from the fertilisation environment (Jamieson et al., 1993; Lee and Jamieson, 1993). In anurans, fertilisation environments can be diverse; consequently, since spermatozoa are the most diverse cell type, they are expected to exhibit wide evolutionary divergence in their form (Pitnick, Hosken, and Birkhead, 2009). The relationship between spermatozoal ultrastructure and spawning location has been discussed for certain anurans (Garda et al., 2004; Muto and Kubota, 2013).

The morphology of the male reproductive organs can present anatomical variants in shape and size, according to the reproductive period (Asenjo et al., 2011). Many studies have focused on cell and morphology changes in the testes and seminiferous tubules throughout the anuran reproductive cycle (e.g. Alves Santos, Santana, and Pacheco, 2017; Asenjo et al., 2011; Carezzano and Cabrera, 2010; Curi, Olea, Álvarez, Céspedez, and Lombardo, 2014). However, the associations between testicular morphology and egg-laying mode out of the water, have been notoriously less explored (Leite et al., 2015).

The anuran genus Leptodactylus (74 species) is divided into four species groups: Leptodactylus latrans, Leptodactylus melanonotus, Leptodactylus pentandactylus, and Leptodactylus fuscus (Heyer, 1969; de Sá, Grant, Camargo, Heyer, Ponssa, and Stanley, 2014). There are four reproductive modes reported for Leptodactylus (Haddad and 
Prado, 2005): 1) eggs in aquatic foam nests and exotrophic tadpoles in ponds (mode $11)$; 2) foam nests floating on water accumulated in constructed basins and exotrophic tadpoles in ponds (mode 13); 3) foam nests with eggs and early larval stages in subterranean nests built after flooding; and 4) exotrophic tadpoles in ponds (mode 30), or streams (mode 31). These two latter modes are typical of species of the group L. fuscus, and of species of the related genus Adenomera. The testicular histomorphology of species of the genus Leptodactylus that lay eggs out of water (such as species of the group L. fuscus) has not been described yet.

It is the aim of the present study to describe the testicular histology and structural characteristics of the germ cells during development and maturation of male gametes, and their cystic arrangement in Leptodactylus latinasus, a member of the group $L$. fuscus with terrestrial egg deposition. The characteristics observed in $L$. latinasus are compared with those of other species with egg deposition out of the water Leptodactylus bufonius, Leptodactylus fuscus, Phyllomedusa boliviana, Phyllomedusa sauvagii, Pithecopus azureus, and Oreobates discoidalis, in order to propose particularities of testicular morphology that contribute to the reproductive success of these species of anurans with egg-laying out of water.

\section{MATERIALS AND METHODS}

Seven species with egg deposition outside the water were selected: Leptodactylus latinasus, L. bufonius and L. fuscus (Leptodactylidae) lay their eggs in foam placed in underground terrestrial incubation chambers, where tadpoles hatch and complete their development in water bodies (Heyer, 1969; Solano, 1987) (Mode 12, Duellman and Trueb, 1986; Mode 30, Haddad and Prado, 2005). Phyllomedusa boliviana, Ph. sauvagii and Pithecopus azureus (Phyllomedusidae) lay their eggs in nests made of leaves hanging over water bodies, and larvae complete their development in the water (Ihering, 1886; Vaira, 2001; Pyburn and Glidewell, 1971) (Mode 18, Duellman and Trueb, 1986; Mode 24, Haddad and Prado, 2005). Oreobates discoidalis (Craugastoridae) eggs are laid directly on the ground, in moist and protected places, and their development is direct (Köhler, 2000; Vaira, 2002) (Mode 17, Duellman and Trueb, 1986; Mode 27, Haddad and Prado, 2005).

Leptodactylus latinasus was used as a comparative model among the studied species since it is known that this species is well adapted to anthropogenic pressure (Ponssa and Barrionuevo, 2008). That allowed us to have a greater sample availability and, therefore, to determine all stages of cystic spermatogenesis during the development and maturation of male gametes.

Specimens were collected during the reproductive period (October 2008 to March 2017) in Northern Argentina localities: San Pablo, Lules, San Javier, Yerba Buena, Tafi Viejo, San Miguel de Tucumán (Tucumán), and Salta Capital (Salta). (Table 2).

Males were anaesthetised with 10\% Xylocaine spray solution. The testes were removed through an abdominal incision and photographed by using a Leica EZ4 simple stereoscopic microscope. They were fixed in $10 \%$ buffered formalin $(0,2 \mathrm{M}$, 
$\mathrm{pH} 7$ ) and were preserved in $70 \%$ ethanol, dehydrated in a series of graded ethanolsolutions, cleared in xylene, and embedded in paraffin. Serial sections (4 to $5 \mu \mathrm{m}$ thick) were cut in a transverse plane with a microtome Zeiss HYRAX S30. The remaining testes were embedded with Cryoplast (freezing mounting medium), at a temperature between $-20^{\circ} \mathrm{C}$ to $-30^{\circ} \mathrm{C}$, thin cuts $(3$ to $4 \mu \mathrm{m}$ thick) were made on these samples with Cryostat Zeiss HYRAX C25, which allowed the identification of the gametes throughout the different stages of spermatogenesis.

Sections were stained with hematoxylin-eosin (H\&E), for the detection of the different cells and tissues as components according to their acidic and basic groups (nucleus and cytoplasm). Although this coloration was used for histomorphological demonstrations, it has histochemical value, since Hematoxylin, due to its basophilia, has an affinity for the acidic groups of glucides and proteins. Eosin, on the other hand, reacts in a specific way in the basic proteins (Martoja and Martoja Pierson, 1970). To identify histones, protamines, and nucleic acids we used the nuclear basic dye toluidine blue (TB) at $\mathrm{pH} \mathrm{4,4} \mathrm{and} \mathrm{7,} \mathrm{which} \mathrm{stains} \mathrm{tissues} \mathrm{based} \mathrm{on} \mathrm{the} \mathrm{prin-}$ ciple of metachromasia (Sridharan and Shankar, 2012). Tissues rich in histones are stained violet-blue; while chromatin rich in protamines_is stained blue (Pearse, 1960; Barkaand Anderson, 1965; Humason, 1979).

The present work is an exhaustive study carried out on numerous histological sections of testicles belonging to each of the different specimens of the species studied, which were observed under an optical microscope ZEISS Lab.A1, with a ZEISS AxioCam ERc5s camera, and Leica DM2000 with Leica ICC50HD camera. Microscopic measurements were performed with a Leica LAZ V4.9 Software.

The histological preparations were added to the Anatomo-Histological Collection belonging to the Institute of Animal Morphology of Foundation Miguel Lillo. (Table 2).

\section{RESULTS}

\section{Testicular morphology of Leptodactylus latinasus}

Macroscopically, the male gonads of Leptodactylus latinasus are asymmetrical, paired, smooth, and oval organs. They are located in the abdominal cavity and linked to the kidney through a thin, vascularised, innervated, connective tissue covered with mesothelial cells. The testicles are $2154.77 \pm 74.29 \mu \mathrm{m}$ long and $1199.28 \pm 47.34$ $\mu \mathrm{m}$ wide $(\mathrm{N}=14)$; fat bodies are associated with the cephalic area of the gonads. The testicles are surrounded by a thin capsule of connective tissue: the tunic albuginea, which is $4.667 \pm 0.726 \mu \mathrm{m}$ thick and confers them a light-yellow colour (unpigmented) (Figs 1, 2) (Table 1). This connective tissue has blood vessels, collagen fibres, fibroblasts, muscle cells, and nerves (Figs 3, 4, 26). Within the testes, there are several seminiferous tubules forming the testicular parenchyma, which is surrounded by a stroma of connective tissue: the peritubular tunic. This tunic originates from the albuginea tunic; and is part of the connective tissue that forms the interstice, where blood vessels, collagen fibres, fibroblasts, macrophages, and Leydig 
cells can be observed (Figs. 5, 6). In the testicular interstitium, there are efferent ducts made up of a simple cuboidal epithelium in the lumen of which spermatozoa can be distinguished (Fig. 3).

\section{Spermatogenesis of Leptodactylus latinasus}

Seminiferous tubules. - Inside the seminiferous tubules, two cell groups can be identified: germ cells and Sertoli cells. The latter are responsible for the maturation of the spermatozoa lineage (Figs. 7, 8). The germ cells are undergoing different stages of spermatogenesis. Spermatogenesis occurs in groups called cysts, which are found inside the seminiferous tubules. Each cyst consists of a single type of germ cells in the same differentiation stage. L. latinasus showed a large number of cysts, containing primary and secondary spermatogonia (Figs. 7, 8), primary and secondary spermatocytes (Figs. 9, 10), spermatids (Figs. 9, 10, 11), and spermatozoa (Figs. 7, $9,12)$. The Sertoli cells are cylindrical with a large euchromatic nucleus in a basal position, prominent nucleolus, and acidophilic cytoplasm. Up to three Sertoli cells were identified in each cyst, probably due to the large cyst size (Figs. 6, 8, 11, 12).

The different developmental stages of the germ cells throughout spermatogenesis are classified by the cell size, cytoplasmic and nuclear characteristics (chromatin size and degree of compaction). In L. latinasus, we observed all the stages of the spermatic cycle (spermatogonia, spermatocyte and spermiogenesis).

Spermatogonia. - Primary spermatogonia of $5.96 \pm 0.21 \mu \mathrm{m}$ of diameter, which are diploid cells characterised as being much larger than the other germ cells. They present a clear nucleus and chromatin with a thin, granular appearance and are divided by mitosis, giving rise to secondary spermatogonia of $4.76 \pm 0.18 \mu \mathrm{m}$ of diameter. The secondary spermatogonia are discretely smaller, and their chromatin is slightly more condensed than in primary spermatogonia. That is because their nuclei have several small sectors of heterochromatin, which gives them greater basophilia (Figs. $7,8)$. Both primary and secondary spermatogonia stain with TB and show a $\beta$-metachromasia, with blue-violet nuclei due to the presence of histones (Figs. 9, 10).

Spermatocytes. - These cells originate from the secondary spermatogonia. Their presence indicates the beginning of the first meiotic division (Figs. 9, 10). The spermatocytes show more condensed chromatin concentration, and they are smaller than the spermatogonia. The primary spermatocytes in different phases of the first meiotic division are discernible as diplotene, metaphase and anaphase, (Fig. 9). The chromosomes in diplotene are observed as large pieces. In the metaphase, the chromosomes are arranged throughout the equatorial region. During anaphase, the chromatids are separated and located at the poles of the cells. As a result of the first meiotic division, secondary spermatocytes are observed, which are characteristically smaller (3.16 \pm $0.11 \mu \mathrm{m}$ of diameter) than the primary spermatocytes. They exhibit more nuclear compaction, show a strong basophilia with H\&E (Figs. 4, 6), and orthochromasia with TB at pH 7 and 4,4 (Figs. 9, 10). 
Spermatids. - The secondary spermatocytes division generates primary spermatids, which are small and spherical approximately $1.62 \pm 0.165 \mu \mathrm{m}$ diameter. Throughout spermiogenesis, spermatid differentiation and nuclear elongation can be observed in 'step' stages. The spermatids are differentiated and give rise to spermatozoa, which allows the observation of spermatids in the first (spermatid 1) and second (spermatid 2) stage of spermiogenesis. During the spermiogenesis, chromatin condensation, cell size modification, and changes in the shape of the nuclei that goes from oval to cylindrical are observed. Spermatids in the first stage of spermiogenesis are spherical and disposed in groups in the cyst (Fig. 9) while spermatids in the second stage of spermiogenesis have an oval nucleus and are organised in bundles attached to the apical zone of the Sertoli cells (Fig. 8, 10, 11, 12). Both primary and secondary spermatids have a nucleus with strong basophilia due to chromatin condensation.

Spermatozoa- - Spermatids in the second stage of spermiogenesis generate spermatozoa, which are elongated cells with totally compacted chromatin (Figs. 9-12). Mature spermatozoa present elongated cylindrical nuclei (total length $=9.37 \mu \mathrm{m}$ diameter $=1.05 \pm 0.07 \mu \mathrm{m}$ ), with their anterior end slightly pointed and arrowshaped. Posterior to the nucleus is the acidophilic flagellum. The spermatozoa are arranged in groups resembling eyelashes in the apical region of the Sertoli cell; while free spermatozoa are already in the lumen of the tubule (Fig. 12).

In the testicle samples of Leptodactylus latinasus, three stages of the reproductive cycle are distinguished: (1) Testicles with cysts in early spermatogenesis stages with a greater number of spermatogonia and spermatocytes, few spermatids, and empty tubule lumen (Fig. 11); (2) Testicles with a large number of cysts, with cells in advanced stages of spermatogenesis (secondary spermatogonia and secondary spermatocytes), spermatids in the first and second stages of spermiogenesis, spermatozoa anchored to the apical region of the Sertoli cell, and free ones in the lumen of the tubule (Fig. 3, 10); (3) Testicles in regression with many cysts with germ-line cells in apoptosis, observed through morphological and biochemical characteristics of the process: DNA fragmentation, reduction of cell volume, cytoplasmic vacuolisation, and formation of apoptotic bodies (Fig. 6).

\section{Comparative study of the testes}

When comparing Leptodactylus latinasus to the other studied species (Leptodactylus bufonius, L. fuscus, Phitecopus azurea, Phyllomedusa boliviana, Phyllomedusa sauvagii, Oreobates discoidalis), variations in both, testicular morphology and spermatogenesis are observed.

Testicular pigmentation, thickness and/or abundance of the albuginea tunic, peritubular tunic, interstitial tissue, and spermatozoon shape stand out. In all the studied species, testes are unpigmented due to the absence of chromatophores (Figs. 13, 16, 19), and show size variation (Figs. 14, 17, 20). The albuginea tunic, constituted by dense irregular connective tissue varies from two to three layers in Leptodactylus latinasus (Fig. 4), L. fuscus, Oreobates discoidalis (Fig. 21) and L. bufonius (Fig. 
15); from four to eight layers in Pithecopus azureus, Phyllomedusa sauvagii (Fig. 18) and P. boliviana.

The peritubular tunic constitutes a thick layer of connective tissue with peritubular myoid cells, fibroblasts and collagen fibres (Figs. 22, 25, 28). The connective tissue that forms the interstitium is dense, but it is characterised not only by an abundance of collagen fibres but also by an abundance of cells. The interstitial tissue, in turn, shows variations between species (Figs. 23, 26, 29); in Phyllomedusa boliviana the abundance of interstitial tissue and the presence of smooth muscle cells stand out (Fig. 26).

Three morphologies are observed among the spermatozoa: (a) Arrow-shaped spermatozoa in Family Leptodactylidae (Fig. 24); (b) curved nail-shaped spermatozoa in Family Phyllomedusidae; in the spermatozoa head region of Phyllomedusa boliviana, two very acidophilous sectors are observed: the anterior acrosome, and the midpiece of the flagellum in the posterior region of the nucleus (Fig. 27); (c) in Family Craugastoridae, long thin sperm of filamentous aspect, Oreobates discoidalis (Fig. 30).

The observed variations in the selected characters among species are synthesised in Table 1.

Regarding spermatogenesis, differences in the development and maturation stages of the germ cells are observed. Leptodactylus bufonius presents cysts with secondary spermatogonia, a few cysts with secondary spermatocytes and spermatids in the second stage of spermiogenesis. This species shows abundant spermatozoa attached to the Sertoli cells, in the tubular lumen and the efferent duct (Fig. 31). Leptodactylus fuscus shows abundant cysts with primary and secondary spermatogonia, secondary spermatocytes, and few spermatozoa attached to the Sertoli cells. These features would indicate that most of the germ cells are in the initial stage of spermatogenesis (Fig. 32). Phitecopus azurea shows an abundance of cysts with secondary spermatogonia, secondary spermatocytes, and spermatozoa attached to the Sertoli cells. These features correspond to advanced spermatogenesis, but not to the final stage since there are no free spermatozoa observed in the lumen of the seminiferous tubule (Fig. 33). In Phyllomedusa boliviana, we found few cysts with primary spermatogonia, abundant cysts with secondary spermatogonia, and secondary spermatocytes and spermatozoa attached to the apical pole of the Sertoli cells. The lumen of the seminiferous tubule and those of the efferent duct are empty. Spermatogenesis is at a similar stage as in P. azurea (Fig. 34). Phyllomedusa sauvagii shows abundant cysts with secondary spermatogonia and secondary spermatocytes, spermatids in the second stage of spermiogenesis, and spermatozoa attached to the Sertoli cells, both in the tubular lumen. These features would indicate complete spermatogenesis and abundant release of mature sperm (Fig. 35). Cysts with secondary spermatogonia abound in Oreobates discoidalis, spermatids in the second stages of spermiogenesis and spermatozoa anchored in the apical region of Sertoli cells, as well as spermatozoa in the process of being released into the light of the seminiferous tubule, indicating a final stage in the spermatogenesis (Fig. 36). 


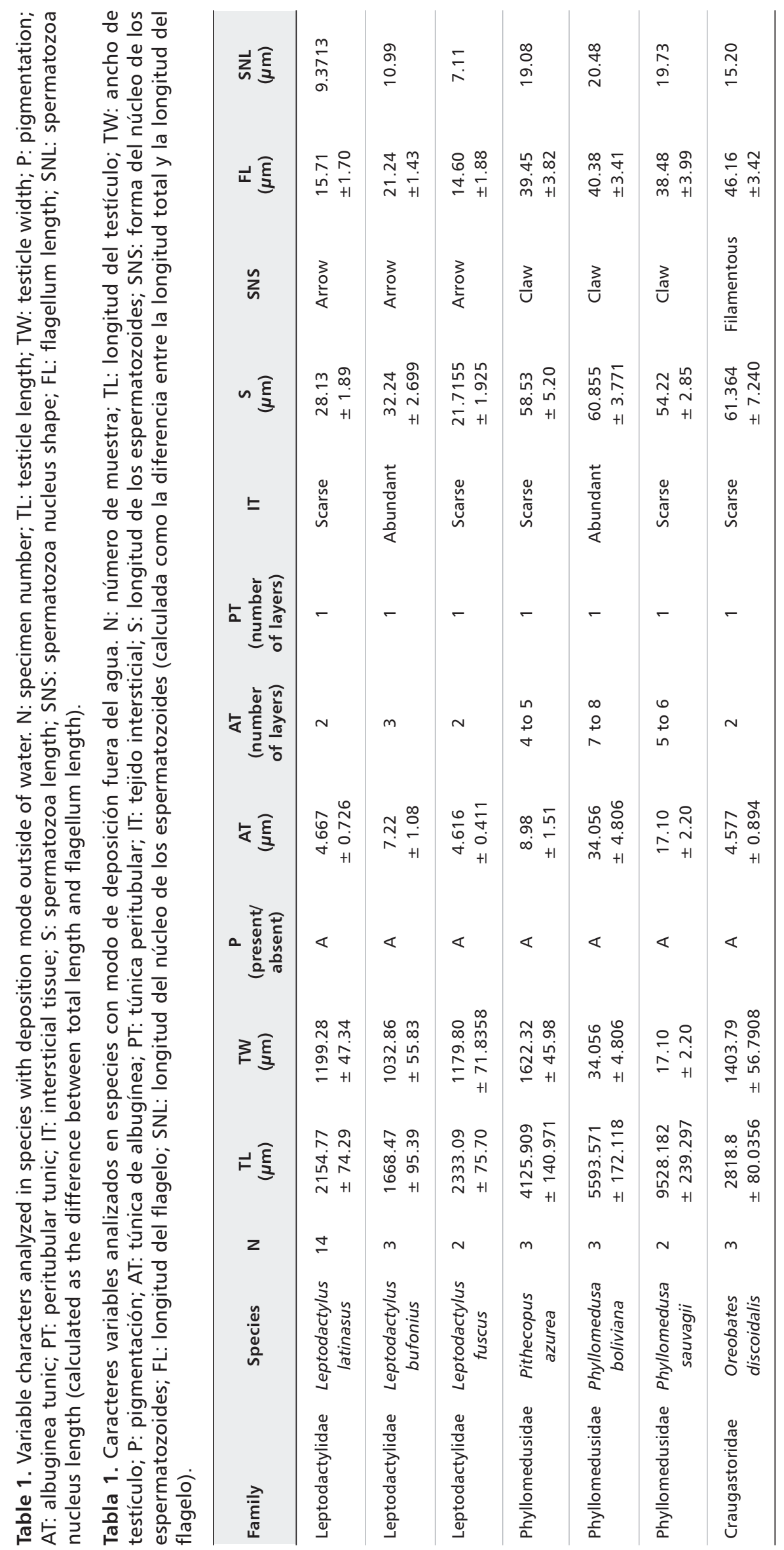


Table 2. List of species examined. Colección Anatomo-Histológica, Instituto de Morfología Animal (Dirección de Zoología, Fundación Miguel Lillo).

Tabla 2. Lista de especies examinadas. Colección Anatomo-Histológica, Instituto de Morfología Animal (Dirección de Zoología, Fundación Miguel Lillo).

\begin{tabular}{|c|c|c|c|}
\hline Species & $\begin{array}{c}\text { Number of } \\
\text { collections } \\
\text { (histological samples) }\end{array}$ & $\begin{array}{l}\text { Collection dates } \\
\text { in brakes } \\
(\mathrm{dd} / \mathrm{mm} / \mathrm{yy})\end{array}$ & $\begin{array}{l}\text { Collection } \\
\text { location }\end{array}$ \\
\hline \multirow[t]{14}{*}{ Leptodactylus latinasus } & APLL0002 & 06/III/2007 & Lules (Tucumán) \\
\hline & APLL0025 & 04/XII/2008 & Lules (Tucumán) \\
\hline & APLL0030 & 04/XII/2008 & Tafí Viejo (Tucumán) \\
\hline & APLL0033 & XII/2011 & Tafí Viejo (Tucumán) \\
\hline & APLL0035 & XII/2011 & San Javier (Tucumán) \\
\hline & APLL0036 & $\mathrm{XII} / 2013$ & San Javier (Tucumán) \\
\hline & APLL0037 & XII/2015 & San Pablo (Tucumán) \\
\hline & APLL0038 & $\mathrm{XI} / 2015$ & San Pablo (Tucumán) \\
\hline & APLL0039 & $\mathrm{XI} / 2015$ & S. M. de Tucumán (Tucumán) \\
\hline & APLL0040 & $\mathrm{XI} / 2015$ & San Pablo (Tucumán) \\
\hline & APLL0041 & $\mathrm{XI} / 2015$ & San Pablo (Tucumán) \\
\hline & APLL0042 & $\mathrm{XI} / 2015$ & Yerba Buena (Tucumán) \\
\hline & APLL0043 & $\mathrm{XI} / 2015$ & Yerba Buena (Tucumán) \\
\hline & APLL0044 & $\mathrm{XI} / 2015$ & Yerba Buena (Tucumán) \\
\hline \multirow[t]{3}{*}{ Leptodactylus bufonius } & APLB0001 & $25 / I 1 / 2006$ & Salta Capital (Salta) \\
\hline & APLB0002 & $20-23 / I 1 / 2010$ & Salta Capital (Salta) \\
\hline & APLB0003 & 08/II/2005 & Salta Capital (Salta) \\
\hline \multirow[t]{2}{*}{ Leptodactylus fuscus } & APLF0003 & $03 / \mathrm{I} / 2018$ & Salta Capital (Salta) \\
\hline & APLF0004 & $09 / 1 / 2018$ & Salta Capital (Salta) \\
\hline \multirow[t]{3}{*}{ Pitherocopus azureus } & APPA0007 & $13 / \mathrm{I} / 2017$ & Salta Capital (Salta) \\
\hline & APPA0009 & $13 / \mathrm{I} / 2017$ & Salta Capital (Salta) \\
\hline & APPA0011 & $13 / \mathrm{l} / 2017$ & Salta Capital (Salta) \\
\hline \multirow[t]{3}{*}{ Phyllomedusa boliviana } & APPB0001 & $15 / \mathrm{I} / 2017$ & Salta Capital (Salta) \\
\hline & APPB0002 & $15 / \mathrm{I} / 2017$ & Salta Capital (Salta) \\
\hline & APPB0003 & $15 / I / 2017$ & Salta Capital (Salta) \\
\hline \multirow[t]{2}{*}{ Phyllomedusa sauvagii } & APPS0004-1 & $24 / X I / 2016$ & San Javier (Tucumán) \\
\hline & APPS0009 & $12 / \mathrm{XII} / 2002$ & Salta Capital (Salta) \\
\hline \multirow[t]{3}{*}{ Oreobates discoidalis } & APOD0007 & $\mathrm{XI} / 2013$ & Lules (Tucumán) \\
\hline & APOD0008 & $\mathrm{XI} / 2013$ & Lules (Tucumán) \\
\hline & APOD0009 & $\mathrm{XI} / 2013$ & Lules (Tucumán) \\
\hline
\end{tabular}



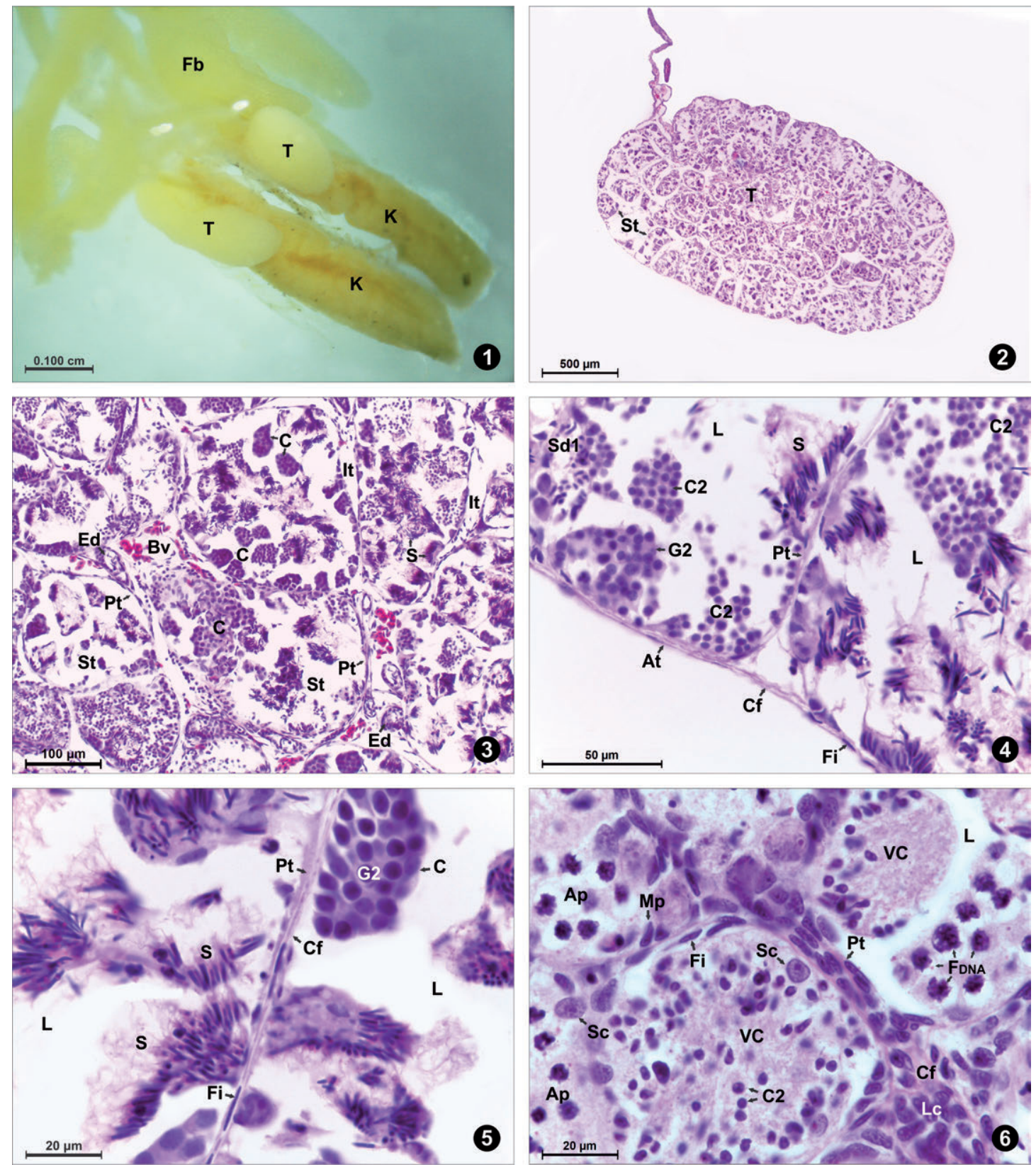

Figure 1. Macroscopic views showing oval unpigmented Testes associated with Fat Bodies and Kidneys in Leptodactylus latinasus. Fb: Fat Body; T: Testis; K: Kidney.

Figura 1. Vistas macroscópicas que muestran testículos ovalados no pigmentados asociados con cuerpos grasos y riñones en Leptodactylus latinasus. Cg: Cuerpo Graso; T: Testículo; R: Riñón.

Figure 2. Histological section of the Testis in L. latinasus. T: Testis; St: Seminiferous tubules. Staining: Hematoxylin-Eosin (H-E).

Figura 2. Corte histológico del testículo en L. latinasus. T: Testículo; Ts: Túbulos seminíferos. Tinción: Hematoxilina-eosina (H-E).

Figure 3. Arrangement of the Seminiferous Tubules in L. latinasus. Bv: Blood vessel; C: Cysts; Ed: Efferent duct; It: Interstitial tissue; Pt: Peritubular tunic, S: Spermatozoa; St: Seminiferous tubules. Staining: H-E.

Figura 3. Disposición de los Túbulos Seminíferos en L. latinasus. Vs: Vaso sanguíneo; C: Cistos; Ce: Conducto eferente; Ti: Tejido intersticial; Tp: Túnica peritubular; E: Espermatozoides; Ts: Túbulos seminíferos. Tinción: H-E. 
Figure 4. Albuginea Tunic in L. latinasus. At: Albuginea tunic; C2: Secondary Spermatocyte; Cf: Collagen fibres; Fi: Fibroblasts; G2: Secondary Spermatogonia; L: Tubule Lumen; Pt: Peritubular tunic; S: Spermatozoa; Sd1: Primary Spermatid. Staining: H-E.

Figura 4. Túnica Albugínea en L. latinasus. Ta: Túnica Albugínea; Ec2: Espermatocito Secundario; Fc: Fibras de colágeno; Fi: Fibroblastos; Eg2: Espermatogonias Secundarias; L: Lumen Tubular; Tp: Túnica peritubular; E: Espermatozoides; Ed1: Espermátida Primaria. Tinción: H-E.

Figure 5. Peritubular Tunic in L. latinasus. C: Cysts; Cf: Collagen fibres; Fi: Fibroblasts; G2: Secondary Spermatogonia; L: Tubule Lumen; S: Spermatozoa. Staining: H-E.

Figura 5. Túnica Peritubular en L. latinasus. C: Cistos; Fc: Fibras de colágeno; Fi: Fibroblastos; Eg2: Espermatogonias Secundarias; L: Lumen Tubular; E: Espermatozoides. Tinción: H-E.

Figure 6. Interstitial Tissue in L. latinasus. Ap: Apoptosis; C2: Secondary Spermatocyte; Cf: Collagen fibres; Fi: Fibroblasts; $F_{D N A}$ : DNA fragmentation; L: Tubule Lumen; Lc: Leydig cell; Mp: Macrophage, Pt: Peritubular tunic, Sc: Sertoli cell; CV:Cytoplasmic Vacuolization. Staining: H-E.

Figura 6. Tejido Intersticial en L. latinasus. Ap: Apoptosis; Ec2: Espermatocito Secundario; Fc: Fibras de colágeno; Fi: Fibroblastos; FADN: fragmentación de ADN; L: Lumen Tubular; CL: Célula de Leydig; Ma: Macrófago; Tp: Túnica peritubular; CS: Célula de Sertoli; VC: Vacuolización Citoplasmática. Tinción: H-E. 

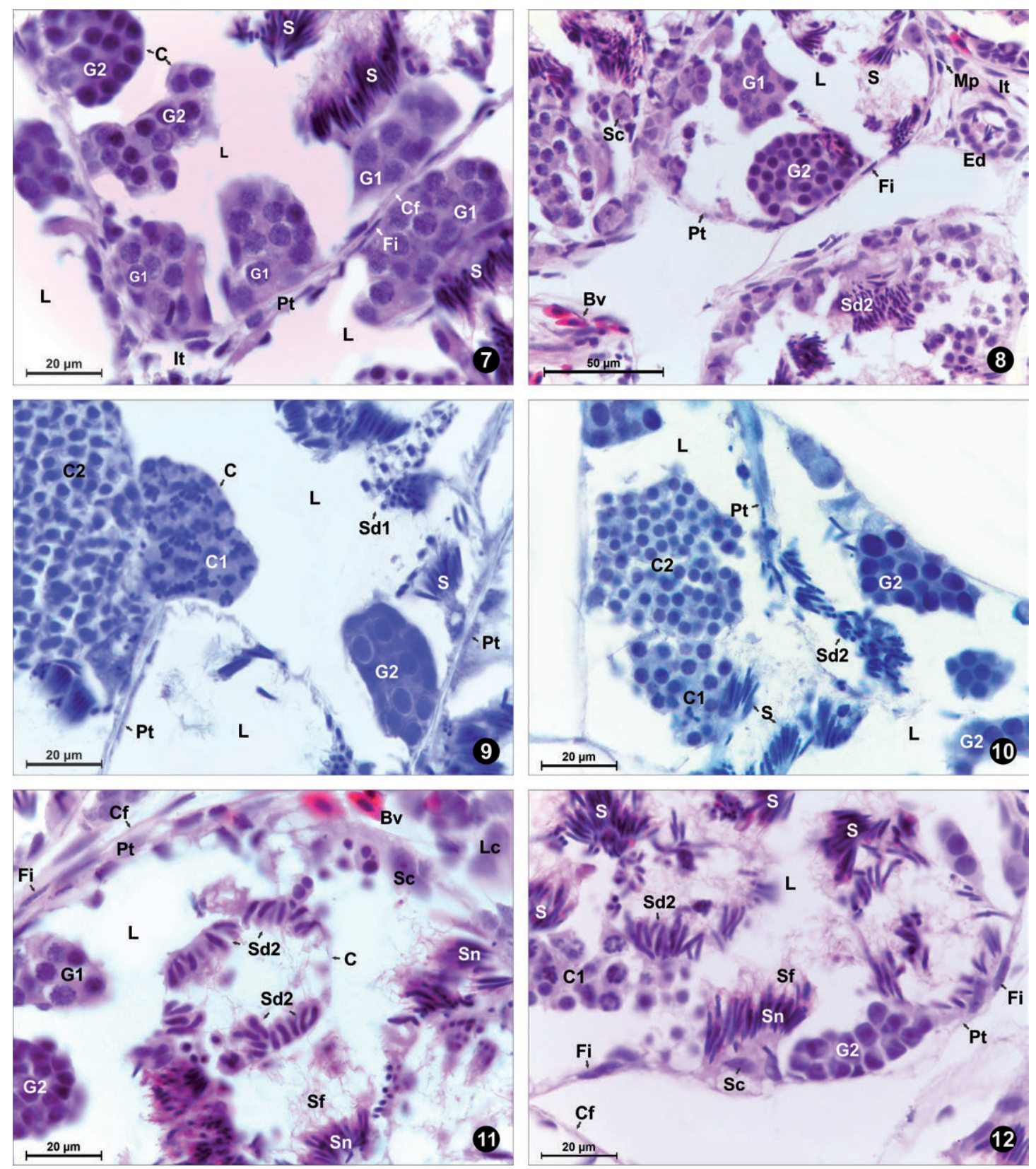

Figure 7. Testicular histology and spermatogenesis of L. latinasus. Cysts with Primary Spermatogonia. C: Cysts; Cf: Collagen fibres; Fi: Fibroblast; G1: Primary Spermatogonia; G2: Secondary Spermatogonia; It: Interstitial tissue; L: Tubule Lumen; Pt: Peritubular tunic; S: Spermatozoa. Staining: Hematoxylin-Eosin (H-E).

Figura 7. Histología testicular y espermatogénesis de L. latinasus. Cistos con Espermatogonias primarias. C: Cistos; Fc: Fibras de colágeno; Fi: Fibroblasto; Eg1: Espermatogonias Primarias; Eg2: Espermatogonias Secundarias; Ti: Tejido intersticial; L: Lumen Tubular; Tp: Túnica peritubular; E: Espermatozoides. Tinción: Hematoxilina-eosina (H-E).

Figure 8. Testicular histology and spermatogenesis of L. latinasus. Cysts with Secondary Spermatogonia. Bv: Blood vessel; Ed: Efferent duct; Fi: Fibroblast; G1: Primary Spermatogonia; G2: Secondary Spermatogonia; It: Interstitial tissue; L: Tubule Lumen; Mp: Macrophages; Pt: Peritubular tunic; S: Spermatozoa; Sc: Sertoli cell; Sd2: Secondary Spermatid. Staining: H-E.

Figura 8. Histología testicular y espermatogénesis de L. latinasus. Cistos con Espermatogonia Secundaria. Vs: Vaso sanguíneo; Ce: Conducto eferente; Fi: Fibroblasto; Eg1: Espermatogonias Primarias; Eg2: Espermatogonias Secundarias; Ti: Tejido intersticial; L: Lumen Tubular; Ma: Macrófagos; 
Tp: Túnica Peritubular; E: Espermatozoides; CS: Células de Sertoli; Ed2: Espermátida Secundaria. Tinción: H-E.

Figure 9. Testicular histology and spermatogenesis of L. latinasus. Cysts with Primary Spermatocytes. C: Cysts; C1: Primary Spermatocyte; C2: Secondary Spermatocyte; G2: Secondary Spermatogonia; L: Tubule Lumen; Pt: Peritubular tunic; S: Spermatozoa; Sd1: Primary Spermatid. Staining: Toluidine Blue pH 7 (TB).

Figura 9. Histología testicular y espermatogénesis de L. latinasus. Cistos con Espermatocitos Primarios. C: Cistos; Ec1: Espermatocito Primario; Ec2: Espermatocito Secundario; Eg2: Espermatogonias Secundarias; L: Lumen Tubular; Tp: Túnica peritubular; E: Espermatozoides; Ed1: Espermátida Primaria. Tinción: Azul de Toluidina pH 7 (AT).

Figure 10. Testicular histology and spermatogenesis of L. latinasus. Cysts with Secondary Spermatocytes. C1: Primary Spermatocyte; C2: Secondary Spermatocyte; G2: Secondary Spermatogonia; L: Tubule Lumen; Pt: Peritubular tunic; S: Spermatozoa; Sd2: Secondary Spermatid. Staining: TB.

Figura 10. Histología testicular y espermatogénesis de L. latinasus. Cistos con Espermatocitos Secundarios. Ec1: Espermatocito Primario; Ec2: Espermatocito Secundario; Eg2: Espermatogonias Secundarias; L: Lumen Tubular; Tp: Túnica peritubular; E: Espermatozoides; Ed2: Espermátida Secundaria. Tinción: AT.

Figure 11. Testicular histology and spermatogenesis of L. latinasus. Cysts with Spermatids. Bv: Blood vessel; C: Cysts; Cf: Collagen fibres; Fi: Fibroblast; G1: Primary Spermatogonia; L: Tubule Lumen; Lc: Leydig cell; Pt: Peritubular tunic; Sc: Sertoli cell; Sd2: Secondary Spermatid; Sf: Spermatozoa flagellum, Sn: Spermatozoa nucleus. Staining: H-E.

Figura 11. Histología testicular y espermatogénesis de L. latinasus. Cistos con Espermátidas. Vs: Vaso sanguíneo; C: Cistos; Fc: Fibras de colágeno; Fi: Fibroblasto; Eg1: Espermatogonias Primarias; L: Lumen Tubular; CL: Célula de Leydig; Tp: Túnica peritubular; CS: Célula de Sertoli; Ed2: Espermátida Secundaria; Fe: Flagelo del espermatozoide; Ne: Núcleo del espermatozoide. Tinción: H-E.

Figure 12. Testicular histology and spermatogenesis of L. latinasus. C1: Primary Spermatocyte; Cf: Collagen fibres; Fi: Fibroblast; G2: Secondary Spermatogonia; L: Tubule Lumen; Pt: Peritubular tunic; S: Spermatozoa; Sd2: Secondary Spermatid; Sf: Spermatozoa flagellum, Sn: Spermatozoa nucleus. Staining: H-E.

Figura 12. Histología testicular y espermatogénesis de L. latinasus. Ec1: Espermatocito Primario; Fc: Fibras de colágeno; Fi: Fibroblasto; Eg2: Espermatogonias Secundarias; L: Lumen Tubular; Tp: Túnica peritubular; E: Espermatozoides; Ed2: Espermátida Secundaria; Fe: Flagelo del espermatozoide; Ne: Núcleo del espermatozoide. Tinción: H-E. 


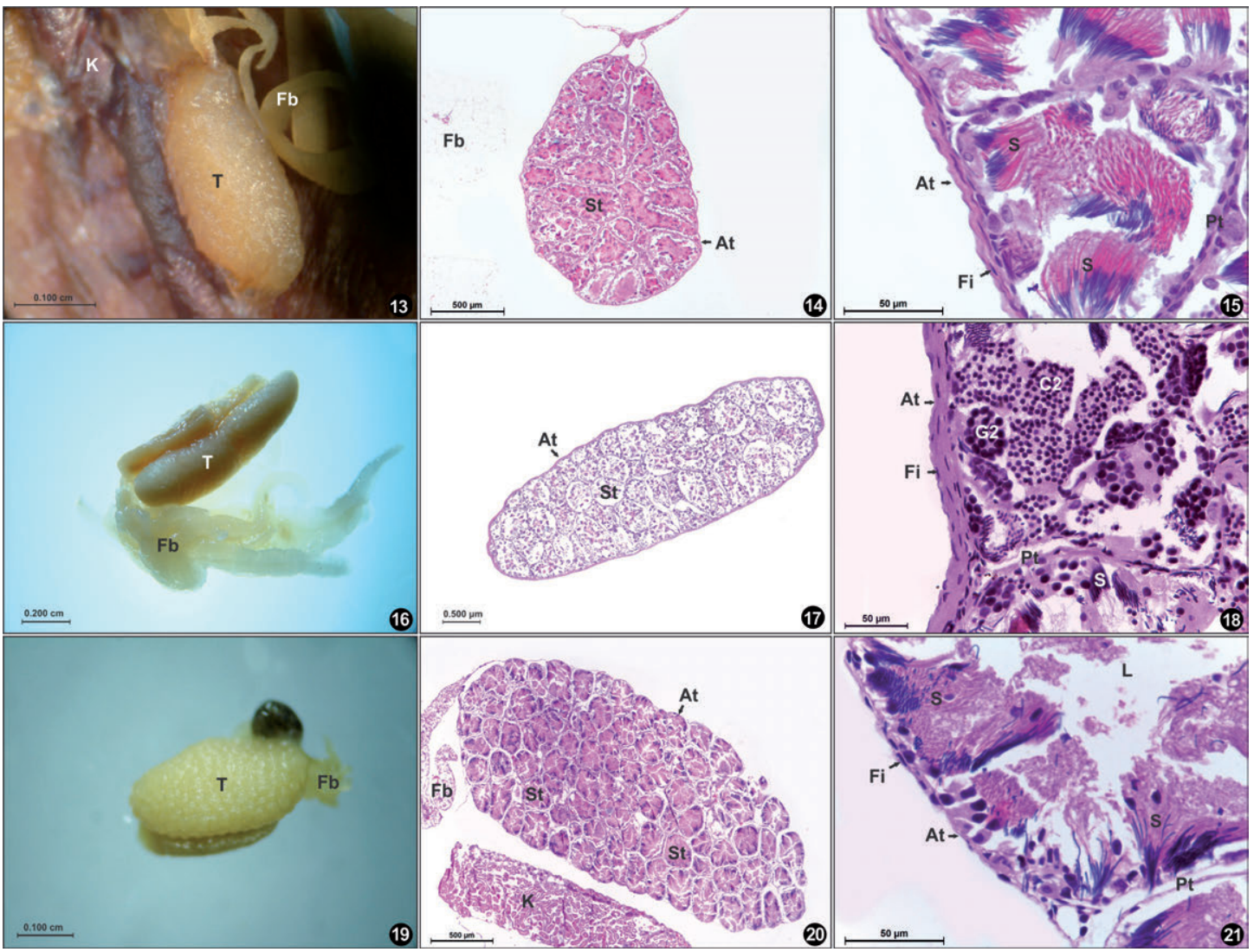

Figure 13. Macroscopy of the testicles showing the unpigmented surface of the organ and its association with fat bodies in Leptodactylus fuscus. Fb: Fat body; T: Testicle.

Figura 13. Macroscopia de los testículos que muestra la superficie no pigmentada del órgano y su asociación con cuerpos grasos en Leptodactylus fuscus. Cg: Cuerpo graso; T: testículo.

Figure 14. Histological characterisation of the testes in Leptodactylus bufonius. At: Albuginea tunic; Fb: Fat body; St: Seminiferous tubules. Staining: Hematoxylin-Eosin (H-E).

Figura 14. Caracterización histológica de los testículos en Leptodactylus bufonius. Ta: Túnica Albugínea; Cg: Cuerpo graso; Ts: Túbulos seminíferos. Tinción: Hematoxilina-Eosina (H-E).

Figure 15. Histological characterisation of the testes in Leptodactylus bufonius. At: Albuginea tunic; Fi: Fibroblasts; S: Spermatozoa. Staining: H-E.

Figura 15. Caracterización histológica de los testículos en Leptodactylus bufonius. Ta: Túnica albugínea; Fi: Fibroblastos; E: Espermatozoides. Tinción: H-E.

Figure 16. Macroscopy of the testicles showing the unpigmented surface of the organ and its association with fat bodies in Phyllomedusa sauvagii. Fb: Fat body; T: Testicle.

Figura 16. Macroscopia de los testículos que muestra superficie no pigmentada del órgano y su asociación con cuerpos grasos en Phyllomedusa sauvagii. Cg: Cuerpo graso; T: Testículo.

Figure 17. Histological characterisation of the testes in Phyllomedusa boliviana. At: Albuginea tunic; St: Seminiferous tubules. Staining: H-E.

Figura 17. Caracterización histológica de los testículos en Phyllomedusa boliviana. Ta: Túnica albugínea; Ts: Túbulos seminíferos. Tinción: H-E.

Figure 18. Histological characterisation of the testes in Phyllomedusa sauvagii. At: Albuginea tunic; C2: Secondary Spermatocyte; Fi: Fibroblasts; G2: Secondary Spermatogonia; Pt: Peritubular tunic; S: Spermatozoa. Staining: H-E.

Figura 18. Caracterización histológica de los testículos en Phyllomedusa sauvagii. Ta: Túnica albugínea; Ec2: Espermatocito Secundario; Fi: Fibroblastos; Eg2: Espermatogonias Secundarias; Tp: Túnica peritubular; E: Espermatozoides. Tinción: H-E. 
Figure 19. Macroscopy of the testicles showing the unpigmented surface of the organ and its association with fat bodies in Oreobates discoidalis. Fb: Fat body; T: Testicle.

Figura 19. Macroscopia de los testículos que muestra la superficie no pigmentada del órgano y su asociación con cuerpos grasos en Oreobates discoidalis. Cg: Cuerpo graso; T: Testículo.

Figure 20. Histological characterisation of the testes in Oreobates discoidalis. At: Albuginea tunic; C2: secondary spermatocyte; Fb: Fat body; K: Kidney; St: Seminiferous tubules. Staining: H-E.

Figura 20. Caracterización histológica de los testículos en Oreobates discoidalis. Ta: Túnica albugínea; Ec2: Espermatocito Secundario; Cg: Cuerpo graso; R: riñón; Ts: Túbulos seminíferos. Tinción: H-E.

Figure 21. Histological characterisation of the testes in Oreobates discoidalis. At: Albuginea tunic; Fi: Fibroblasts; L: Tubule Lumen; Pt: Peritubular tunic; S: Spermatozoa. Staining: H-E.

Figura 21. Caracterización histológica de los testículos en Oreobates discoidalis. Ta: Túnica albugínea; Fi: Fibroblastos; L: Lumen Tubular; Tp: Túnica peritubular; E: Espermatozoides. Tinción: H-E. 


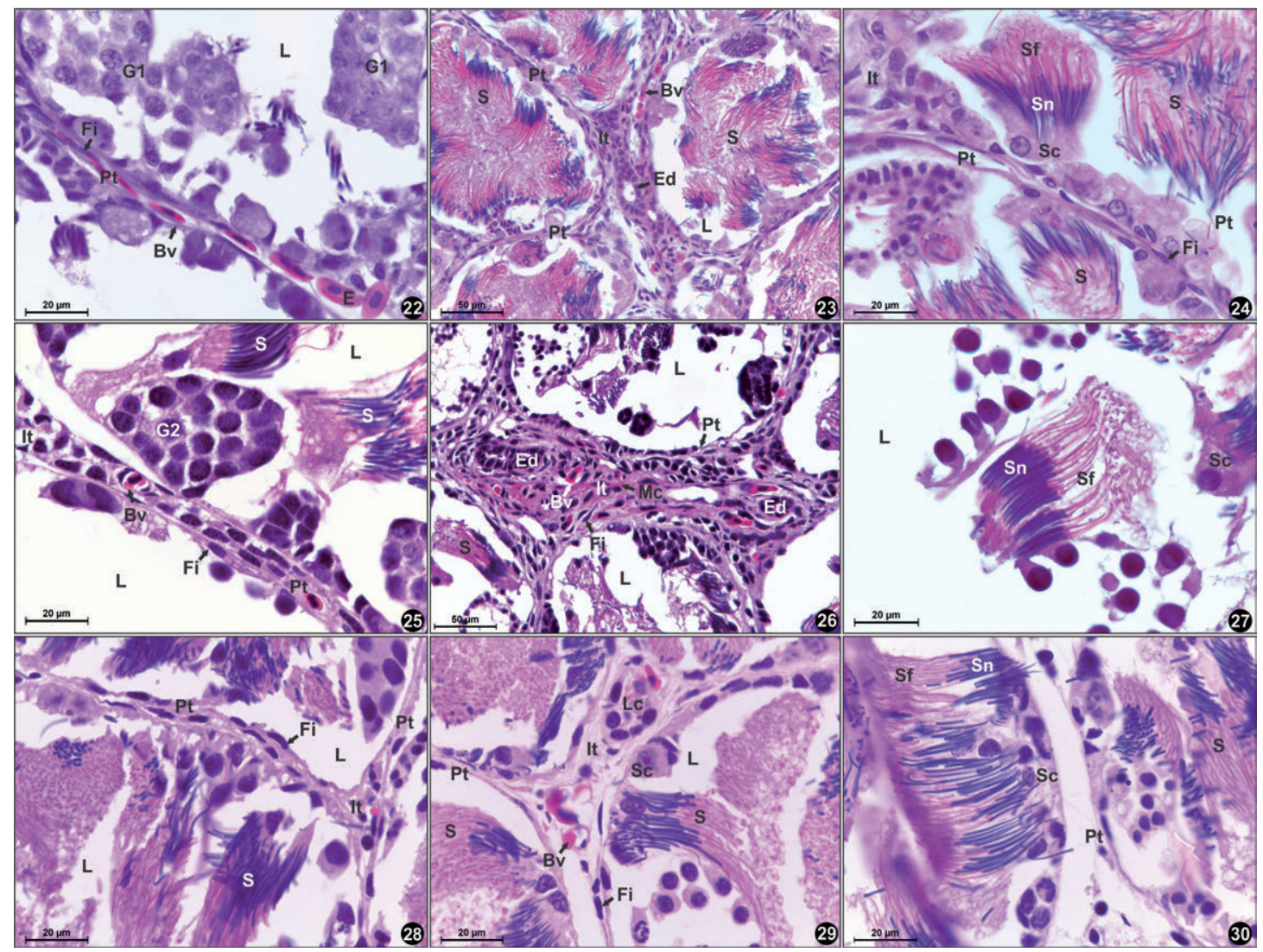

Figure 22. Histological characterisation and spermatogenesis of the testes in Leptodactylus fuscus. Bv: Blood vessel; E: Erythrocyte; Fi: Fibroblast; G1: Primary Spermatogonia; L: Tubule Lumen; Pt: Peritubular Tunic. Staining: Hematoxylin-Eosin (H-E).

Figura 22. Caracterización histológica y espermatogénesis de los testículos en Leptodactylus fuscus. Vs: Vaso sanguíneo; Er: Eritrocito; Fi: Fibroblast; Eg1: Espermatogonias Primarias; L: Lumen Tubular; Tp: Túnica peritubular. Tinción: Hematoxilina-Eosina (H-E).

Figure 23. Testicular histology and spermatogenesis of Leptodactylus bufonius. Bv: Blood vessel; Ed: Efferent conduct; L: Tubule Lumen; Pt: Peritubular tunic; S: Spermatozoa. Staining: H-E.

Figura 23. Histología testicular y espermatogénesis de Leptodactylus bufonius. Vs: Vaso sanguíneo; Ce: Conducto eferente; L: Lumen Tubular; Tp: Túnica Peritubular; E: Espermatozoides. Tinción: H-E.

Figure 24. Testicular histology and spermatogenesis of Leptodactylus bufonius. Fi: Fibroblast; It: interstitial tissue; Pt: Peritubular tunic; S: Spermatozoa; Sc: Sertoli cell; Sf: Spermatozoa flagellum; Sn: Spermatozoa nucleus. Staining: H-E.

Figura 24. Histología testicular y espermatogénesis de Leptodactylus bufonius. Fi: Fibroblasto; Ti: Tejido intersticial; Tp: Túnica peritubular; E: Espermatozoides; CS: Célula de Sertoli; Fe: Flagelo del espermatozoide; Ne: Núcleo del espermatozoide. Tinción: H-E.

Figure 25. Testicular histology and spermatogenesis of Pithecopus azureus. Bv: Blood vessel; Fi: Fibroblast; G2: Secondary Spermatogonia; It: Interstitial tissue; L: Tubule Lumen; Pt: Peritubular tunic; S: Spermatozoa. Staining: H-E.

Figura 25. Histología testicular y espermatogénesis de Pithecopus azureus. Vs: Vaso sanguíneo; Fi: Fibroblasto; Eg2: Espermatogonias Secundarias; Ti: Tejido intersticial; L: Lumen Tubular; Tp: Túnica peritubular; E: Espermatozoides. Tinción: H-E.

Figure 26. Testicular morphology of Phyllomedusa boliviana. Bv: Blood vessel; Ed: Efferent conduct; Fi: Fibroblast; Mc: muscle cells; L: Tubule Lumen; Pt: Peritubular tunic. It: interstitial tissue. Staining: H-E.

Figura 26. Morfología testicular de Phyllomedusa boliviana. Vs: Vaso sanguíneo; Ce: Conducto eferente; Fibroblasto; $\mathrm{Cm}$ : células musculares: L: Lumen Tubular: Tp: Túnica peritubular. Ti: tejido intersticial. Tinción: H-E. 
Figure 27. Testicular histology and spermatogenesis of Phyllomedusa boliviana. L: Tubule Lumen; Sc: Sertoli cell; Sf: Spermatozoa flagellum; Sn: Spermatozoa nucleus. Staining: H-E.

Figura 27. Histología testicular y espermatogénesis de Phyllomedusa boliviana. L: Lumen Tubular; CS: Célula de Sertoli; Fe: Flagelo del espermatozoide; Ne: Núcleo del espermatozoide. Tinción: H-E.

Figure 28. Histological characterisation and spermatogenesis of Craugastoridae species. Photomicrographs showing the peritubular tunic in detail in Oreobates discoidalis. Fi: Fibroblast; It: interstitial tissue; L: Tubule Lumen; Pt: Peritubular tunic; S: Spermatozoa. Staining: H-E.

Figura 28. Caracterización histológica y espermatogénesis de especies de Craugastoridae. Microfotografías que muestran en detalle la túnica peritubular en Oreobates discoidalis. Fi: fibroblasto; It: tejido intersticial; L: lumen tubular; Pt: túnica peritubular; S: espermatozoides. Tinción: H-E.

Figure 29. Testicular histology and spermatogenesis of Oreobates discoidalis. Bv: Blood vessel; E: erythrocyte; Fi: Fibroblast; It: interstitial tissue; L: Tubule Lumen; Lc: Leydig cell; Pt: Peritubular tunic; S: Spermatozoa. Staining: H-E.

Figura 29. Histología testicular y espermatogénesis de Oreobates discoidalis. Vs: Vaso sanguíneo; Er: Eritrocito; Fi: Fibroblasto; Ti: Tejido intersticial; L: Lumen Tubular; CL: Célula de Leydig; Tp: Túnica peritubular; E: Espermatozoides. Tinción: H-E.

Figure 30. Testicular histology and spermatogenesis of Oreobates discoidalis. Photomicrographs showing the spermatozoa in detail. Pt: Peritubular tunic; S: Spermatozoa; Sc: Sertoli cell; Sf: Spermatozoa flagellum; Sn: Spermatozoa nucleus. Staining: H-E.

Figura 30. Histología testicular y espermatogénesis de Oreobates discoidalis. Microfotografías que muestran los espermatozoides en detalle. Tp: Túnica peritubular; E: Espermatozoides; CS: Célula de Sertoli; Fe: Flagelo del espermatozoide; Ne: Núcleo del espermatozoide. Tinción: H-E. 

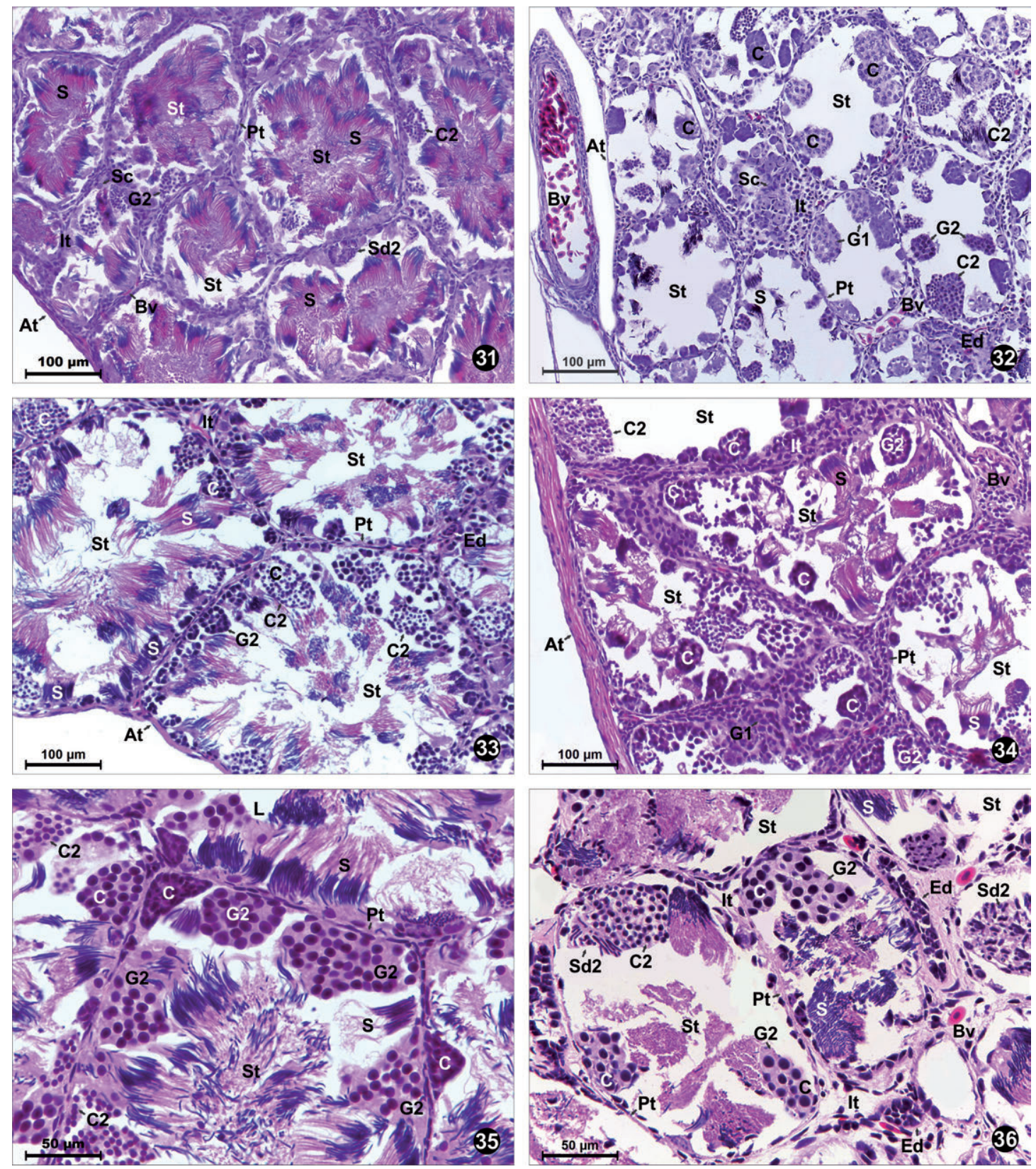

Figure 31. Testicular histology and spermatogenesis of Leptodactylus bufonius. At: Albuginea tunic; Bv: Blood vessel; C2: Secondary Spermatocyte; G2: Secondary Spermatogonia; It: Interstitial tissue; Pt: Peritubular tunic, S: Spermatozoa; Sc: Sertoli cell; St: Seminiferous tubules; Sd2: Secondary Spermatid. Staining: Hematoxylin-Eosin (H-E).

Figura 31. Histología testicular y espermatogénesis de Leptodactylus bufonius. Ta: Túnica albugínea; Vs: Vaso sanguíneo; Ec2: Espermatocito Secundario; Eg2: Espermatogonias Secundarias; Ti: Tejido intersticial; Tp: Túnica peritubular; CS: Célula de Sertoli; Ts: Túbulos seminíferos; Ed2: Espermátida Secundaria. Tinción: Hematoxilina-eosina (H-E).

Figure 32. Testicular histology and spermatogenesis of Leptodactylus fuscus. At: Albuginea tunic; Bv: Blood vessel; C: Cysts; C2: Secondary Spermatocyte; Ed: Efferent duct; G1: Primary Spermatogonia; G2: Secondary Spermatogonia; It: Interstitial tissue; Pt: Peritubular tunic, S: Spermatozoa; Sc: Sertoli cell; St: Seminiferous tubules. Staining: H-E.

Figura 32. Histología testicular y espermatogénesis de Leptodactylus fuscus. Ta: Túnica albugínea; Vs: Vaso sanguíneo; C: Cistos; Ec2: Espermatocito Secundario; Ce: Conducto eferente; Eg1: Espermatogonias Primarias; Eg2: Espermatogonias Secundarias; Ti: Tejido intersticial; Tp: Túnica peritubular; E: Espermatozoide; CS: Célula de Sertoli; Ts: Túbulos seminíferos. Tinción: H-E. 
Figure 33. Testicular histology and spermatogenesis of Pithecopus azureus. At: Albuginea tunic; C: Cysts; C2: Secondary Spermatocyte; Ed: Efferent duct; G2: Secondary Spermatogonia; It: Interstitial tissue; Pt: Peritubular tunic, S: Spermatozoa; St: Seminiferous tubules. Staining: H-E.

Figura 33. Histología testicular y espermatogénesis de Pithecopus azureus. Ta: Túnica albugínea; C: Cistos; Ec2: Espermatocito Secundario; Ce: Conducto eferente; Eg2: Espermatogonias Secundarias; Ti: Tejido intersticial; Tp: Túnica peritubular; E: Espermatozoides; Ts: Túbulos seminíferos; Tinción: H-E.

Figure 34. Testicular histology and spermatogenesis of Phyllomedusa boliviana. At: Albuginea tunic; It: interstitial tissue; Bv: Blood vessel; C: Cysts; C2: Secondary Spermatocyte; G1: Primary Spermatogonia; G2: Secondary Spermatogonia; It: Interstitial tissue; Pt: Peritubular tunic, S: Spermatozoa; St: Seminiferous tubules. Staining: H-E.

Figura 34. Histología testicular y espermatogénesis de Phyllomedusa boliviana. Ta: Túnica albugínea; Ti: Tejido intersticial; Vs: Vaso sanguíneo; C: Cistos; Ec2: Espermatocito Secundario; Eg1: Espermatogonias Primarias; Eg2: Espermatogonias Secundarias; Ti: Tejido intersticial; Tp: Túnica peritubular; E: Espermatozoides; Ts: Túbulos seminíferos. Tinción: H-E.

Figure 35. Testicular histology and spermatogenesis of Phyllomedusa sauvagii. C: Cysts; C2: Secondary Spermatocyte; G2: Secondary Spermatogonia; L: Tubule Lumen, Pt: Peritubular tunic, S: Spermatozoa; St: Seminiferous tubules. Staining: H-E.

Figura 35. Histología testicular y espermatogénesis de Phyllomedusa sauvagii. C: Cistos; Ec2: Espermatocito Secundario; Eg2: Espermatogonias Secundarias; L: Lumen Tubular; Tp: Túnica peritubular; E: espermatozoides; Ts: Túbulos seminíferos. Tinción: H-E.

Figure 36. Testicular histology and spermatogenesis of Oreobates discoidalis. Bv: Blood vessel; C: Cysts; C2: Secondary Spermatocyte; Ed: Efferent duct, G2: Secondary Spermatogonia; It: Interstitial tissue; Pt: Peritubular tunic, S: Spermatozoa; Sd2: Secondary Spermatid, St: Seminiferous tubules. Staining: H-E.

Figura 36. Histología testicular y espermatogénesis de Oreobates discoidalis. Vs: Vaso sanguíneo; C: Cistos; Ec2: Espermatocito Secundario; Ce: Conducto eferente; Eg2: Espermatogonias Secundarias; Ti: Tejido intersticial; Tp: Túnica peritubular; E: Espermatozoides; Ed2: Espermátida Secundaria; Ts: Túbulos seminíferos. Tinción: H-E. 


\section{DISCUSSION}

In the present study, we describe the histomorphology of the testes of Leptodactylus latinasus. We also identify morphological traits of the testes that vary among species of different families with egg deposition out of the water, and with three different reproductive modes. Certain specific characters do not differ at the family level, but they do at the species level. However, the observed variations suggest that the hypothesis of a relationship between these features and phylogeny needs to be confirmed by future phylogenetic comparative analyses.

Despite the wide diversity of the genus Leptodactylus (75 sps., Frost, 2020), only the histological aspects of the spermatozoa of Leptodactylus ocellatus (Rosemblit, Pozzi, and Ceballos, 2006), Leptodactylus labyrinthicus (Prado, Abdala, Silva, and Zina, 2004), Leptodactylus podicipinus (Ferreira, dos Santos Rosa, and Mehanna, 2009), and Leptodactylus chaquensis (Ferreira et al., 2009; Iruzubieta Villagra et al., 2012) have been analysed. In Leptodactylus latinasus, males build chambers with their snouts, where amplexus takes place, the construction of the foam nest occurs, and the earlier larval stages develop, even before the first rains (Gallardo, 1958, 1964). The larvae complete their development in temporal puddles. This behaviour would be an advantage for this species over others that develop in the same water body since at the beginning of the rainy season L. latinasus larvae are already in more advanced stages of development (Heyer, 1969). This particular breeding behaviour and the capacity of the tadpoles to generate their own foam allow the species to survive in the case of prolonged drought periods (Downie, 1984, 1989, 1990, 1994; Caldwell and Lopez, 1989; Downie and Smith, 2003; Ponssa and Barrionuevo, 2008).

The presence of testicles with many cysts in apoptosis found in L. latinasus specimens could be related to the climatic conditions of the sampled year, which was especially dry (4/12/2008, Lules, Tucumán). Thus, the temporary water bodies might have been absent, or soil moisture might not have been optimal for the construction of the nuptial chamber, where the amplexus and the first stage of larval development occur. Female specimens of $L$. latinasus collected during the drought months of the same year (2008) showed ovaries in the process of atresia (Pucci Alcaide et al., 2012). Alterations in the periods of activity and quiescence are related to climatic conditions (Rastogi, Lela, Saxena, Chieffi, 1976).

A remarkable characteristic was the large size of the testis in species with arboreal egg deposition. For example, the testis of the smallest Phyllomedusidae species studied (Pithecopus azureus SVL $=38.64 \pm 0.96 \mathrm{~cm}$ ), were larger than those of the largest Leptodactylidae species (Leptodactylus fuscus SVL $=99.99 \pm 2.58$ ). This feature does not seem to be related to terrestrial breeding, but it is rather considered as an excellent example of adaptation to spermatozoa competition (Emerson, 1997; Ramm and Scharer, 2014). Many species with multiple breeding have relatively larger testes compared to other species without this behaviour (Kusano, Toda, and Fukuyama, 1991; Jennions and Passmore, 1993; Emerson, 1997; Prado and Haddad, 2003). To be more precise, this behaviour was reported in P. Azureus (Dias, Maragno, Prado, and Cechin, 2012). This relationship was also observed in other Rhacophoridae arboreal species, e.g. Rhacophorus arboreus (Kusano et al., 1991) 
and Chiromantis xerampelina (Jennions and Passmoren, 1993), but also in species of the genus Leptodactylus, L. chaquensis and L. podicipinus (Prado and Haddad, 2003). Other ways in which testicles can regulate spermatozoa production are independent of testicle size, such as increases in the proportion of spermatogenic tissue (Ramm and Scharer, 2014), or testis morphology (Leite et al., 2015).

The thickness and number of layers of the albuginea tunic revealed a significant variation among the studied species, from a thin tunic composed by one layer in Oreobates discoidalis, to being composed of six or more layers in Phyllomedusa boliviana. The more noticeable number of layers corresponded to Phyllomedusa boliviana and $P$ sauvagii, which exhibited approximately five and two times the maximum value of that of other studied species, respectively. Differences in the thickness of the albuginea tunic have been reported in Hylodids and Leiuperines (Leite et al., 2015), and in Eleutherodactylus species (Rodríguez Gómez, Sanz Ochotorena, Segura Valdés, Martínez, and Jiménez García, 2012). The latter authors proposed that these variations might indicate that species with more terrestrial habits tend to be more protective of their seminiferous tissue from solar radiation and other physical aggressions, compared to those inhabiting areas closer to water. In Phyllomedusa boliviana and P. sauvagii, the positive relationship between the size of the testicle and the increase of the albuginea tunic could be associated with the need for protecting and supporting larger testes and a greater number of seminiferous tubules. That relationship could also be related to an increase in the smooth muscle cells, which would be necessary for the compression of the testicle, and the movement of the spermatozoa from the seminiferous tubules to the efferent ducts. Moreover, there is evidence supporting the fact that these parameters can be adjusted according to environmental conditions (Rammand Scharer, 2014).

A previously analysed characteristic in the tissues here studied is the presence of pigmentation. A common state of character among the species studied here is the lack of testicular pigmentation (e.g., the presence of milky white testes), which is a usual trait in anurans (Oliveira and Zieri, 2005, Asenjo et al., 2011; Duellman and Trueb, 1986). The absence of pigmented cells has been reported in several leptodactylid species (Franco-Belucci, Zieri, de Souza Santos, Moresco, Oliveira, 2009), and a weak pigmentation has only been observed in Leptodactylus furnarius and Adenomera bokermanni (as Leptodactylus bokermanni) (Franco-Belussi et al., 2009). Testicular pigmentation has also been described in Leiuperidae (Aoki, Vitale-Calpe, and Pisano, 1969; Carezzano and Cabrera, 2010; Oliveira and Zieri, 2005; Oliveira et al., 2002, 2003; Franco-Belussi et al., 2009), and in species of Colestethus (Grant, 2004). This extracutaneous pigmentary system still exerts an unknown function (Zuasti, JimenezCervantes, García-Barrón and Ferrer, 1998; Franco-Belussi et al., 2009), although it has been suggested to be linked to spermatogenesis thermoregulation (Guillette, Weigeland Flater, 1983), to the protection of sperm from oxidative stress (Almbro, Dowling and Simmons, 2011), or to the amount of pre-mating sexual investment (Rammand Scharer, 2014). Our data do not support this last hypothesis, since the investment of Leptodactylus species of the fuscus group and Phyllomedusa species in the construction of nests of mud and leaves, respectively, occurs before mating and they do not present testicular pigmentation. 
The cells of the spermatic lineage of the studied species have similar characteristics as those observed in other species (e.g. Oliveira et al., 2002, Jamieson et al., 1993, Oliveira et al., 2005, Carrezano et al., 2010, Iruzubieta Villagra, Ramos, Cisint, Crespo, and Fernández, 2017). Among the species studied, differences in the abundance of cysts during the spermatogenesis process would be related to the reproductive moment in which the studied specimens are found. The early onset of thyroid development appears to be related to direct developmental evolution in anuran amphibians (Goldberg J., Taucce Pedro P.G., Quinzio Silvia Ines, Haddad Celio F.B. and Vera Candioti Florencia, 2020). The shape of sperm nuclei distinguishes the samples of the studied families. The spermatozoal nucleus contains DNA and nuclear proteins, and its shape might be determined by the DNA-protein association patterns (Báo, Dalton, and Oliveira, 1991). The nucleus occupies a significant part of the head, and its shape ultimately determines the shape of the spermatozoa head. In order to guarantee fertilisation, several factors are involved, including environmental conditions, cell-cell interactions, gene expression, and phenotypic spermatozoa traits (Zeng, Ling Lou, Bo Liauo, and Jehle, 2014; García Vázquez, Gadea, Matás, and Holt, 2016); thus, head morphology and tail size would influence the selection of the spermatozoa that reach the fertilisation place. In anurans, the nuclear morphology is quite variable (Zeng et al., 2014), and, in this study, we recorded three morphological patterns: arrow (Leptodactylidae); claw (Phyllomedusidae), and filamentous (Craugastoridae). Other described shapes include a pointed head in Ranidae, and a spindle-shaped head in Bombina bombina (as Bombina torigneus) (Blüm, 2012). In mammals, the influence of the shape of the spermatozoa heads over hydrodynamics was found to be considerable (Gomendio and Roldan, 2008; Firman and Simmons, 2010). Further, several studies have evaluated the relationship between spermatozoa morphology and fertility, which varies intraspecifically; thus, it is not possible to propose a single cause of the observed differences between mammal species (García Vazquez et al., 2016). The site where spermatozoa compete is apparently related to interspecific differences (Gomendio and Roldan, 2008). In animals with internal fertilisation, spermatozoa face different physical barriers and undergo complex interactions (García Vazquez et al., 2016). Within the female reproductive tract, mammalian spermatozoa are exposed to more complex influencing factors than fish spermatozoa in water, since the spermatozoa must swim along epithelial surfaces (Nosrati, Driouchi, Yip, and Sinton, 2015). Anurans select environmental conditions that maximise mating success (Anssi, 2006; Indermaur, Schaub, Jokela, Tockner, and Schmidt, 2010).

The three reproductive modes exhibited by the studied species are related to different fertilisation environments: open-air in Phyllomedusidae (Ihering, 1886); foam nests produced by female oviductal secretions and deposits in incubation chambers of mud on land in Leptodactylus of the L. fuscus group (Heyer, 1978); and direct development in Oreobates discoidalis (Akmentis, 2011; Goldberg, J., Vera Candioti, F. and Akmentins, M. S., 2012; Vitt and Caldwell, 2013). These three reproductive modes showed three different sperm head morphologies, which is probably an adaptive advantage that favours fertilisation. 
The ratio between head and tail length might be a good predictor of the swimming speed of the spermatozoa (Gomendio and Roldan, 2008). The variation in spermatozoa length has been related to spermatozoa swimming speed since it has been hypothesised that spermatozoa competition among species can favour longer spermatozoa with higher swimming speed (Zeng et al., 2014). This hypothesis is both supported by many authors (Blengini, Naretto, Cardozo, Giojalas, and Chiaraviglio, 2014; Ross-Santaella, Pintus, and Garde, 2015; Simpson, Humphries, Evans, Simmons, and Fitzpatrick, 2013), and rejected by empirical evidence (Hosken, 1997; Anderson and Dixson, 2002; Firman and Simmons, 2010).

In our study, we found differences in this ratio: species with arboreal spawning locations (Phyllomedusidae) showed longer spermatozoa tails than those with terrestrial (Leptodactylus of the group L. fuscus), or direct development (Oreobates discoidalis) (Goldberg et al., 2020). These results partially agree with those found in Chinese frogs, with terrestrial-arboreal spawning species showing longer spermatozoa than species with aquatic spawning (Zeng et al., 2014). The relationship between spermatozoa morphology (spermatozoa head and flagellum length ratio) and swimming speed would be influenced by the fertilisation mode (Simpson et al., 2013).

In the female reproductive tract, the physics of the viscoelastic fluid motion would act on the performance, since the elasticity of the medium implies forces that affect spermatozoa movement and that are not present in water (Lauga, 2007).

In Oreobates discoidalis, the spermatozoa exhibited the longest flagella; however, the flagellum length to head length ratio in this species was similar to that found in species with terrestrial-external fertilisation, and it was smaller than that of species with aerial-external fertilisation. These characters could have a relationship with putting mode out of the water.

In species with external fertilisation, more subtle aspects should be taken into account as responsible for the variations in the relationships between spermatozoa size and speed, e.g. anuran oocytes are covered by an extracellular matrix of oviductal secretions forming a variable number of layers of gelatinous aspect (Alcaide $e t$ al., 2009) through which spermatozoa must swim and penetrate (Reinhart, Ridgway, and Chandler, 1998). Consequently, in anurans, the external environment might be different from that of fishes or molluscs (Simpson et al., 2013), and even among species, since the egg glandular aggregations differ in species with different oviposition modes (Alcaide et al., 2009). That highlights the importance of analysing the anuran urogenital system in a context of spermatozoa morphological coevolution and female reproductive tract morphology.

The most outstanding characters were found in species with egg deposition in trees (family Phyllomedusidae). Some of the described features can be related to species deposition modes which imply different environmental conditions, e.g. the thickness of albuginea tunic with arboreal breeding, alterations in spermatogenesis development in adverse environmental conditions, variations in spermatozoa shape within fertilisation environments, the ratio between head and tail length with terrestrial or external fertilisation.

Anurans are an excellent group to test specialisations of the urogenital tract in relation to phylogeny or adaptation since they present species with both internal 
and external fertilisation and the greatest variation of reproductive modes among vertebrates. The histomorphological study of the testicles of the species studied in this work allowed us to establish particularities in gonadal morphology and morphological-physiological characteristics of male gametes related to the ways that deposit eggs out of water. In turn, it provides information to understand the success of such a diversity of reproductive modes in the evolutionary history of the group.

\section{ACKNOWLEDGEMENTS}

We express our gratitude to Fundación Miguel Lillo (Z-0075-1) and Agencia Nacional de Promoción Científica y Tecnológica (ANPCyT, for its abbreviation in Spanish) (PICT 2015-1618 to MLP) for providing financial assistance.

\section{PARTICIPATION}

The authors A. Pucci Alcaide and F. Pucci Alcaide planned, designed, and executed the experimental work and A. Pucci Alcaide, F. Pucci Alcaide, A.A. Michel, M.L. Ponssa conducted data analyses and wrote the manuscript.

\section{CONFLICTS OF INTEREST}

The authors declare that there is no conflict of interest.

\section{LITERATURE CITED}

Akmentins, M. S. (2011). Vocal repertoire of two species of Oreobates Jiménez de la Espada, 1872 (Anura: Strabomantidae) of the Yungas Andean Forest, NW Argentina. Fournal of Natural History, 45(29-30), 1789-1799.

Alcaide, M. F., Lavilla, E. O., and Pucci Alcaide, A. (2009). Histology and Histochemistry of the Albumin Glands in Some Foam-Nesting Anurans. South American Fournal of Herpetology, 4(2), 151-163.

Almbro, M., Dowling, D. K., and Simmons, L. W. (2011). Effects of vitamin E and beta-carotene on sperm competitiveness. Ecology Letters, 14, 891-895.

Alves Santos, M. T., Santana, D. J., and Pacheco, C. M. (2017). Caracterização histomorfológica dos testículos de Dendropsophus nanus (Boulenger, 1889) (Anura, Hylidae). Enciclopedia Biosfera, 14(16) 892-900.

Anderson, M. J., and Dixson, A. F. (2002). Motility and the midpiece in primates. Nature International Fournal of Science, 416, 496.

Anssi, L. (2006). Breeding habitat selection and larval performance of two anurans in freshwater rock-pools. Ecography, 21, 484-494. 
Aoki, A., Vitale-Calpe, R., and Pisano, A. (1969). The testicular interstitial tissue of the Amphibian Physalaemus fuscumaculatus. Z. Zellforsch, 98(1), 9-16.

Asenjo, A., Siu Ting, K., and Pino, J. (2011). Morfometría de testículo y células germinales de Allobates femoralis (Boulenger 1883) (Dendrobatidae: Anura: Amphibia). The Biologist (Lima), 9(2), 167-175.

Báo, S. N., Dalton, G. C., and de Oliveira, S. F. (1991). Spermiogenesis in Odontophrynus cultripes (Amphibia, Anura, Leptodactylidae): Ultrastructural and cytochemical studies of proteins using E-PTA. Fournal of Morphology, 207(3), 303-314.

Barka, T., and Anderson, P. J. (1965). Histochemistry Theory, Practice and Bibliography. Hoeber Medical division: Harper Row, Publishers, inc. New York, Evanston, and London Press, 660 pp.

Blengini, C. S., Naretto, S., Cardozo G., Giojalas, L. C., and Chiaraviglio, M. (2014). Variability in sperm form and function in the context of sperm competition risk in two Tupinambis lizards. Ecology and Evolution, 4(21), 4080-4092.

Blüm, V. (2012). Vertebrate reproduction. Springer Science and Business Media, 405 pp. Caldwell, J. P., and Lopez, P. T. (1989). Foam-generating behavior in tadpoles of Leptodactylus mystaceus. Copeia, 2, 498-502.

Carezzano, F. J., and Cabrera, M. R. (2010). Morfohistología del testículo de Physalaemus biligonigerus (Amphibia, Leiuperidae). Boletín de la Asociación Herpetológica Española, 21, 39-43.

Cruz, J.C., Ferraro, D. P., Farías, A., Santos, J. S., Recco-Pimentel, S. M., Faivovich, J., and Hermida, G. N. (2016). A comparative ultrastructural analysis of spermatozoa in Pleurodema (Anura, Leptodactylidae, Leiuperinae). Fournal of Morphology, 277(7), 957-977.

Curi, L. M., Olea, G. B., Álvarez, B. B., Céspedez, J. A., and Lombardo, D. M. (2014). Reproductive aspects of Dendropsophus sanborni (Anura, Hylidae) in northeastern Argentina. Iheringia, Série Zoología, 104(4), 432-438.

de Sá, R. O., Grant, T., Camargo, A., Heyer, W. R., Ponssa, M. L., and Stanley, E. (2014). Systematics of the Neotropical Genus Leptodactylus Fitzinger, 1826 (Anura: Leptodactylidae): phylogeny, the relevance of non-molecular evidence, and species Accounts. South American Fournal of Herpetology, 9(s1), https://doi. org/10.2994/SAJH-D-13-00022.1

Dias, T. M., Maragno, F. P., Prado, C. P. A., and Cechin, S. Z. (2012). Phyllomedusa azurea. Multimale spawning. Herpetological Review, 43, 634.

dos Santos, J. S., Orlandi Introíni, G., Prado Veiga-Menoncello, A. C., and ReccoPimentel, S. M. (2015). Ultrastructure variation in the spermatozoa of Pseudopaludicola frogs (Amphibia, Anura, Leptodactylidae), with brief comments on its phylogenetic relevance. Fournal of Morphology, 276(12), 1495-1504.

Downie, J. R. (1984). How Leptodactylus fuscus tadpoles make foam, and why. Copeia, 1984(3), 778-780.

Downie, J. R. (1989). Observations on foam-making by Leptodactylus fuscus tadpoles. Herpetological Fournal, 1, 351-355.

Downie, J. R. (1990). Temporal changes in the behavior of foam-making Leptodactylus fuscus tadpoles. Herpetological Fournal, 1, 498-500. 
Downie, J. R. (1994). Developmental arrest in Leptodactylus fuscus tadpoles (Anura: Leptodactylidae). I: descriptive analysis. Herpetological Fournal, 4, 29-38.

Downie, J. R., Disney, R. H. L., Collins, L., and Hancock, E. G. (1995). A new species of Megaselia (Diptera, Phoridae) whose larvae prey upon the eggs of Leptodactylus fuscus (Anura, Leptodactylidae). Fournal of Natural History, 29, 993-1003.

Downie, J. R., and Smith, J. (2003). Survival of Larval Leptodactylus fuscus (Anura: Leptodactylidae) out of water: Developmental Differences and Interspecific Comparisons. Fournal of Herpetology, 37(1), 107-115.

Duellman, W. E. (1985). Reproductive modes in anuran amphibians: phylogenetic significance of adaptive strategies. South African Fournal of Science, 81, 174178.

Duellman, W.E., and Trueb, L. (1986). Biology of Amphibians. The Johns Hopkins University Press, Maryland, 670 pp.

Emerson, S. B. (1997). Testis size variation in frogs: testing the alternatives. Behavioral Ecology and Sociobiology, 41(4), 227-235.

Ferreira, A., dos Santos Rosa, A. B., and Mehanna, M. (2009). Organização celular dos testículos em Hylidae e Leptodactylidae, no Pantanal (Estado do Mato Grosso do Sul, Brasil). Maringá, 31(4), 447-452.

Firman, R. C., and Simmons, L. W. (2010). Sperm midpiece length predicts sperm swimming velocity in house mice. Biology Letters, 6(4), 513-516.

Franco-Belussi, L., Zieri, R. de Souza Santos, L. R., Moresco, R. M., and de Oliveira, C. (2009). Pigmentation in Anuran Testes: Anatomical Pattern and Variation. The Anatomical Record, 292(2), 178-182.

Frost, D. R. (2020). Amphibian Species of the World: an Online Reference. Version 6.0 (Date of access). Electronic Database accessible at http://research.amnh. org/herpetology/amphibia/index.html. American Museum of Natural History, New York, USA.

Gallardo, J. M. (1958). Observaciones biológicas sobre Leptodactylus prognathus Boulenger. Ciencia e Investigación, 14(10-11), 460-465.

Gallardo, J. M. (1964). Leptodactylus prognathus Boul. y Leptodactylus mystacinus (Burm.) con sus respectivas especies aliadas (Amphibia, Leptodactylidae del grupo "Cavícola”). Revista del Museo de Ciencias Naturales "Bernardino Rivadavia." Serie Zoológica, 9(5), 91-121.

García Vázquez, F. A., Gadea, J., Matás, C., and Holt, W. V. (2016). Importance of sperm morphology during sperm transport and fertilization in mammals. Asian Fournal of Andrology, 18, 844-850.

Garda, A. A., Costa, G. C., Colli, G. R., and Báo, S. N. (2004). Spermatozoa of Pseudinae (Amphibia, Anura, Hylidae), with a test of the hypothesis that sperm ultrastructure correlates with reproductive modes in anurans. Fournal of Morphology, 261(2), 196-205.

Goldberg, J., Vera Candioti, F. and Akmentins, M. S. (2012). Direct-developing frogs: ontogeny of Oreobates barituensis (Anura: Terrarana) and the development of a novel trait. Amphibia-Reptilia. Volume 33: Issue 2, 239-250.

Goldberg J., Taucce Pedro P.G., Quinzio Silvia Ines, Haddad Celio F.B., Vera Candioti Florencia. (2020). Increasing our knowledge on direct-developing frogs: 
the ontogeny of Ischnocnema henselii (Anura: Brachycephalidae). Zoologischer Anzeiger. Volume 284, 78-87.

Gomendio, M., and Roldan Eduardo, R. S. (2008). Implications of diversity in sperm size and function or sperm competition and fertility. The International Journal of Developmental Biology, 52, 439-447.

Grant, T. (2004). On the identities of Colostethus inguinalis (Cope, 1868) and C. panamensis (Dunn, 1933), with comments on C. latinasus (Cope, 1863) (Anura: Dendrobatidae). American Museum Novitates, 344, 24 pp.

Guillette, L. J. Jr., Weigel, J., and Flater, G. (1983). Unilateral testicular pigmentation in the Mexican lizard Sceloporus variabilis. Copeia, 1983, 155-161

Haddad, C. F. B., and Prado, C. P. A. (2005). Reproductive modes in frogs and their unexpected diversity in the Atlantic Forest of Brazil. Bioscience, 55(3), 207-217.

Helfenstein, F., Podevin, M., and Richner, H. (2010). Sperm morphology, swimming velocity, and longevity in the house sparrow Passer domesticus. Behavioral Ecology and Sociobiology, 64(4), 557-565.

Heyer, W. R. (1969). The adaptive ecology of the species groups of the genus Leptodactylus (Amphibia, Leptodactylidae). Evolution, 23(3), 421-428.

Heyer, W. R. (1978). Systematics of the fuscus group of the frog genus Leptodactylus (Amphibia, Leptodactylidae). Natural History Museum of Los Angeles County Science Bulletin, 29, 1-85.

Hosken, D. J. (1997). Sperm competition in bats. Proceedings of the Royal Society of London B, 264, 385-392.

Humason, G. (1979). Animal tissue techniques. 4th edition. W. H. Freeman and Company, $661 \mathrm{pp}$.

Ihering, H. von. (1886). On the oviposition in Phyllomedusa iheringii. Annals and Magazine of Natural History, Series 5(17), 461-463.

Indermaur, L., Schaub, M., Jokela, J., Tockner, K., and Schmidt, B. R. (2010). Differential response to abiotic conditions and predation risk rather than competition avoidance breeding site selection by anurans. Ecography, 33, 887-895.

Iruzubieta Villagra, A. L., Cisint, S. B., Crespo, C. A., Medina, M. F., Ramos, I., and Fernández, S.N. (2012). Spermatogenesis in Leptodactylus chaquensis. histologicalstudy. Zygote, 22 (3), 291-299.

Iruzubieta Villagra, L., Ramos, I., Cisint, S., Crespo, C. A., Fernández, S. N. (2017). Electron microscopy observations on testis and spermatozoa of Leptodactylus chaquensis (Anura, Leptodactylidae). Micron, 105, 35-46.

Jamieson, B., Lee, M., and Long, K. (1993). Ultrastructure of the spermatozoon of the internally fertilizing frog Ascaphustruei (Ascaphidae: Anura: Amphibia) with phylogenetic considerations. Herpetologica, 49(1), 52-65.

Jennions, M. D. and Passmoren, I. (1993). Sperm competition in frogs: testis size and a 'sterile male' experiment on Chiromantis xerampelina (Rhacophoridae). Biological Fournal of the Linnean Society, 50(3), 211-220.

Köhler, J. 2000. Amphibian diversity in Bolivia: a study with special reference to montane forest regions. Bonner Zoologische Monographien. 48, 1-262. 
Kusano, T., Toda, M., and Fukuyama, K. (1991). Testes size and breeding systems in Japanese anurans with special reference to large testes in the treefrog, $R h a$ cophorus arboreus (Amphibia: Rhacophoridae). Behavioral Ecology and Sociobiology 29:27-31.

Lauga, E. (2007). Propulsion in a viscoelastic fluid. Physics of Fluids, 19, 083104083113.

Lavilla, E. O., and Rougès, M. (1992). Reproducción y desarrollo de anuros argentinos. Asociación Herpetológica Argentina, Serie Divulgación, 25, 1-66.

Lavilla, E. O. (2004). Reproducción y desarrollo en anuros argentinos. In Montero, R. and Aquino, A. (Eds.), Sistemática y Filogenia de los Vertebrados con Énfasis en la Fauna Argentina. Universidad Nacional de Tucumán, Tucumán, Argentina. 137-143.

Lavilla, E. O., and Rougès, M. (1992). Modos de reproducción de anuros argentinos. Serie Divulgación, Asociación Herpetológica Argentina, 5: 1-66.

Lee, M. S. Y., and Jamieson, B. G. M. (1993). The ultrastructure of the spermatozoa of bufonid and Hylid frogs (Anura, Amphibia): implications for phylogeny and fertilization biology. Zoologica Scripta, 22(3), 309-323.

Leite G. B., Franco-Bellussi L., Provete D. B., and Oliveira C. (2015). Comparative testis morphology of Neotropical anurans. Zoologischer Anzeiger - A Fournal of Comparative Zoology, 257, 29-38.

Lingnau, R., and Di-Bernardo, M. (2006). Predation on foam nests of two Leptodactylid frogs by Solenopsis sp. (Hymenoptera, Formicidae) and Liophismiliaris (Serpentes, Colubridae). Biociências, 14(2), 223-224.

Magnusson, W. E., and Hero, J. M. (1991). Predation and the evolution of complex oviposition behaviour in Amazon rainforest frogs. Oecologia, 86(3), 310-318.

Martins, M. (1993). Observations on nest dynamics and embryonic and larval development in the nest building gladiator frog, Hyla faber. Amphibia-Reptilia, 14, $411-421$.

Martoja, R., and Martoja-Pierson, M. (1970). Técnicas de histología animal. Ed. Toray-Mason SA, Barcelona, España.

Mossman, J., Slate, J., Humphries, S., and Birkhead, T. (2009). Sperm morphology and velocity are genetically codetermined in the zebra finch. Evolution, 63(10), 2730-2737.

Muto, K., and Kubota, H. Y. (2013). Ultrastructure and motility of the spermatozoa of Polypedates leucomystax (Amphibia, Anura, Rhacophoridae). Cytoskeleton, 70(3), 121-133.

Noble, G. K. (1927). The value of life history data in the study of evolution of the Amphibia. Annals of the New York Academy of Sciences, 30, 31-128.

Nosrati, R., Driouchi, A., Yip, C. M., and Sinton, D. (2015). Two-dimensional slither swimming of sperm within a micrometre of a surface. Nature Communications, 6, 8703 .

Oliveira, C, Zanetoni, C, and Zieri, R. (2002). Morphological observations on the testes of Physalaemus cuvieri (Amphibia, Anura). Revista Chilena de Anatomía, 20(3), 263-268. 
Oliveira, C., Sant' Anna, A. C., Munhozde Omena, P. M., de Souza Santos, L. R., and Zieri, R. (2003). Morphological considerations on the seminiferous structures and testes of anuran amphibians: Bufo crucifer, Physalaemus cuvieri and Scinax fuscovarius. Biociências, 11(1), 39-46.

Oliveira C, and Zieri R. (2005). Pigmentaçao testicular em Physalaemus natterer $i$ (Steindachner) (Amphibia, Anura) com observações anatómicas sobre o sistema pigmentar extracutâneo. Revista Brasileira de Zoologia, 22(2), 454-460.

Pearse, E. (1960). Histoquímica teórica y aplicada. Aguilar, Madrid, 597 pp.

Pitnick, S. S., Hosken, D. J., and Birkhead, T. R. (2009). Sperm morphological diversity. In Birkhead, T. R., Hosken, D. J., and Pitnick, S. S. (eds). Sperm biology: an evolutionary perspective. Academics Press, 69-130.

Ponssa, M. L., and Barrionuevo, J. S. (2008). Foam-generating behaviour in tadpoles of Leptodactylus latinasus (Amphibia, Leptodactylidae): Significance in systematics. Zootaxa, 1884, 51-59.

Prado, C. P. A., and Haddad, C. F. B. (2003). Testes size in Leptodactylus frogs and occurrence of multimale spawning in the genus Leptodactylus in Brazil. Fournal of Herpetology, 37 (2), 354-362.

Prado, C. P. A., Abdala, F. C., Silva, A.P. Z., and Zina, J. (2004). Late gametogenesis in Leptodactylus labyrinthicus (Amphibia, Anura, Leptodactylidae) and some ecological considerations. Brazilian Fournal of Morphological Sciences, 21, 177-184.

Prado, C. P. A., Toledo, L. F., Zina, J., and Haddad, C. (2005). Trophic eggs in the foam nests of Leptodactylus labyrinthicus (Anura, Leptodactylidae): An experimental approach. Herpetological fournal, 15(4), 279-284.

Pucci Alcaide, A., Alcaide, M. F., Pucci Alcaide, F. J., and Lavilla, E. O. (2011). The vesicles of Phyllomedusa sauvagii (Anura: Hylidae) nest. South American Fournal of Herpetology, 6(1), 20-26.

Pucci Alcaide, A., Ponssa, M. L., and Pucci Alcaide, F. J. (2012). Histología de ovario en hembras vitelogénicas de Leptodactylus latinasus (Anura, Leptodactylidae). Acta Zoologica Lilloana, 56(1-2), 44-53.

Pyburn, W.F., and Glidewell, J. R. (1971). Nests and breeding behavior of Phyllomedusa hypochondrialis in Colombia. Fournal of Herpetology, 5(1/2), 49-52.

Pyburn, W.F. (1980). The function of eggless capsules and leaf in nests of the frogs Phyllomedusa hypochondrialis (Anura: Hylidae). Proceedings of the Biological Society of Washington, 93(1), 153-167.

Ramm, S. A., and Schärer, L. (2014). The evolutionary ecology of testicular function: size isn't everything. Biological Reviews, 89(4), 874-888.

Rastogi, R. K.; Lela, L.; Saxena, P. K.; Chieffi, G. (1976). The Control of Spermatogenesis in the Green Frog, Rana esculenta. Institute and Museum of Zoology, Faculty of Science, University of Naples, 80134 Naples, Italy. Journal Exp. Zool., 196: 151-166.

Reinhart, D., Ridgway, J., and Chandler, D. E. (1998). Xenopus laevis fertilisation: analysis of sperm motility in egg jelly using video light microscopy. Zygote, 6(2), 173-182.

Rodríguez Gómez, Y., Sanz Ochotorena, A., Segura Valdés, M. L., Martínez, R. L., and Jiménez García, L. F. (2012). Diferencias en la morfología testicular en ranas 
del género Eleutherodactylus (Anura) pertenecientes a tres microhábitats. Primer Congreso Virtual de Ciencias Morfológicas, pp. 1-10.

Rosemblit, C., Pozzi, A. G., and Ceballos, N. R. (2006). Relationship between steroidogenesis and spermiation in Rana catesbeiana and Leptodactylus ocellatus. Fournal of Comparative Physiology B, 176(6), 559-566.

Ross-Santaella, J. L., Pintus, E., and Garde, J. J. (2015). Intramale variation in sperm size: functional significance in a polygynous mammal. Peerf-Life and Environment. doi.org/10.7717/peerj.1478

Salles, N. M. E., Zara, F. J., and Prado, C. P. A. (2017). Differences in sperm morphology in foam-nesting Leptodactyline frogs (Anura, Leptodactylidae). Acta Zoologica Stockholm, 98, 1-12.

Salthe, S. N., and Duellman, W. E. (1973). Quantitative constraints associated with reproductive mode in Anurans. In: VIAL, J. L. ed. Evolutionary biology of the anurans. Contemporary research on major problems. Columbia, University of Missouri. p.229-249.

Salthe, S. N., and Mechan, J. S. (1974). Reproductive and courtship patterns. In: Physiology of the Amphibia, vol. 2, Lofts, B., ed., New York, Academic Press. 309-521.

Scheltinga, D. M., Jamieson, B. G. M., Eggers, K. E., and Green, D. M. (2001). Ultrastructure of the spermatozoon of Leiopelma hochstetteri (Amphibia, Anura, Leiopelmatidae). Zoosystema, 23(1), 157-171.

Simpson, J. L., Humphries, S., Evans, J. P., Simmons, L. W., and Fitzpatrick, J. L. (2013). Relationships between sperm length and speed differ among three internally and three externally fertilizing species. Evolution, 68(1), 92-104.

Solano, H. (1987). Algunos aspectos de la biología reproductiva del sapito silbador Leptodactylus fuscus (Schneider) (Amphibia: Leptodactylidae). Amphibia-Reptilia, 8(2), 111-128.

Sridharan, G., and Shankar, A. A. (2012). Toluidine blue: A review of its chemistry and clinical utility. Fournal of Oral and Maxillofacial Pathology, 16(2), 251-255.

Taylor, D. H., and Gutman, S. I. (1977). The Reproductive Biology of Amphibians, New York: Plenium Press.

Tourmente, M., Gomendio, M., and Roldan, E. R. (2011). Sperm competition and the evolution of sperm design in mammals. BMC Evolutionary Biology, 11,12.

Vaira, M. (2001). Breeding biology of the leaf frog, Phyllomedusa boliviana (Anura, Hylidae). Amphibia-Reptilia, 22(4), 421-429.

Vaira, M. (2002). Anurans of a subtropical montane forest in northwestern Argentina: ecological survey and a proposed list of species of conservation concern. Biodiversity and Conservation, 11, 1047-1062.

Veiga-Menoncello, A. C. P., Lima, A. P., and Recco-Pimentel, S. M. (2006). Sperm morphology of five species of Colostethus (Anura, Dendrobatidae) from Brazil, with phylogenetic comments. Acta Zoologica (Stockholm), 87(2), 147-157.

Vitt, L. J., and Caldwell, J. P. (2013). Herpetology. An Introductory Biology of Amphibians and Reptiles. Fourth Edition, Amsterdam: Elsevier, 776 pp.

Wells, K. W. (2007). The ecology and behavior of amphibians. Chicago: The University of Chicago Press, 1400 pp. 
Zeng, Y., Ling Lou, S., Bo Liao, W., and Jehle, R. (2014). Evolution of sperm morphology in anurans: insights into the roles of mating system and spawning location. Evolutionary Biology, 14,104.

Zuasti, A., Jiménez-Cervantes, C., García-Borrón, J. C., and Ferrer, C. (1998). The melanogenic system of Xenopus laevis. Archives of Histology and Cytology, 61(4), 305-316. 